THE AMERICAN PEDIATRIC SOCIETY

and

\title{
THE SOCIETY FOR PEDIATRIC RESEARCH
}

Combined

Program and Abstracts

The San Francisco Hilton

San Francisco, California

April 27-29, 1977 
THE AMERICAN PEDIATRIC SOCIETY

87 th Annual Meeting

OFFICERS

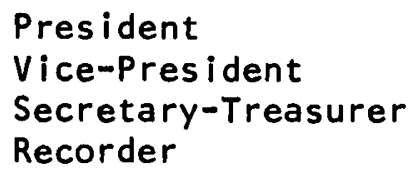

COUNCIL

C. Henry Kempe, Chairman

Moses Grossman Philip R. Dodge Joseph Dancis
Paul G. Quie

Eleanor Colle

Thomas K. Oliver, Jr.

IN MEMORIAM

Warren E. Wheeler

Paul Gyorgy

THE SOCIETY FOR PEDIATRIC RESEARCH

47th Annual Meeting

OFFICERS

\author{
President \\ President-Elect \\ Vice-President \\ Secretary-Treasurer
}

COUNCIL

Sanford N. Cohen

Max D. Cooper

Michael A. Heymann
Frederick C. Battaglia

Frank A. Oski

Richard A. Behrman

Jo Anne Brasel

Rawle M. Mclntosh Joseph D. Schulman W. Allan Walker

Joseph B. Warshaw, Membership Secretary 


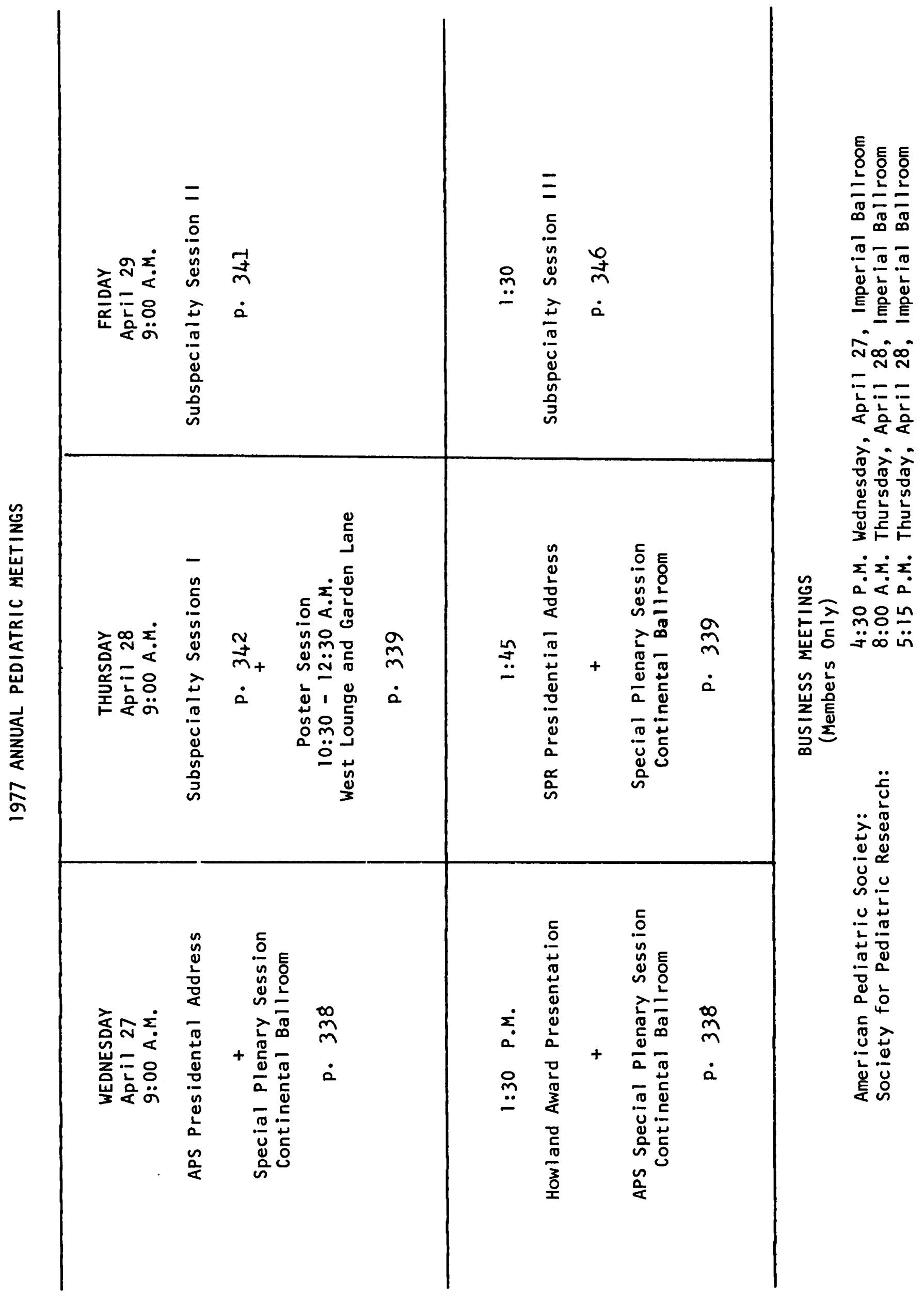


American Pediatric Society

Special Plenary Session (April 27, 9:00 A.M. Continental Ballroom).............. 338

Special Plenary Session (April 27, 1:30 P.M. Continental Ballroom).............. 338

Society for Pediatric Research

Special Plenary Session (April 28, 1:45 P.M. Continental Ballroom)............... 339

Subspecialty Sessions:

Adolescent Medicine (April 29, A.M. California Room)...................... 341

Behavioral Science (April 28, A.M. Continental Parlors 1, 2 \& 3).............. 342

Cardiology (April 28 A.M. and April 29 A.M. Continental Ballroom \#5)............ 343

Developmental Blology (April 29, A.M. and P.M. Cypress Room)................. 34.5

Developmental Pharmacology (April 28, A.M. and April 29, A.M.

Continental Ball room \#6) ........................................ 347

Endocrinology (April 28, A.M. and April 29, A.M. Imperial Ballroom)............ 349

Epidemiology (April 29, P.M. Continential Parlors 7, 8 \& 9)................ 351

Gastroenterology and Nutrition (April 28,A.M. and April 29, A.M.

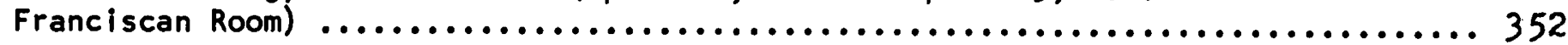

Genetics (April 28, A.M. and April 29, P.M. California Room).................. 354

Hematology and Oncology (April 28, A.M. and April 29, A.M.

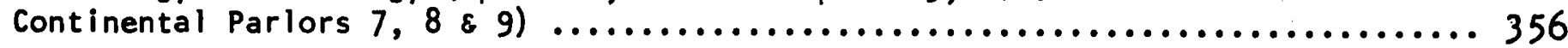

Immunology (April 28, A.M. Pacific Room and April 29, P.M. Hilton Plaza.......... 358

Infectious Disease (April 28 A.M. and April 29, A.M. Hilton Plaza) .............. 360

Metabolism (April 29, A.M. and P.M. Pacific Room)......................... 362

Morphogenesis (April 29, P.M. Cabrillo/Dolores Rooms)...................... 364

Neonatology (April 29, A.M. and April 29, P.M. Continental Ballroom \#4).......... 36'5

Nephrology (April 29, A.M. and April 29, P.M. Continental Parlors 1, 2 \& 3)...... 367

Neurology (April 29, P.M. Anza/Balboa Rooms)............................. 369

Pulmonology (April 28, A.M. Continental Ballroom \#4 and April 29, P.M.

Continental Ballroom \#5)........................................... 370

Poster Session (April 28, A.M. West Lounge) $\ldots \ldots \ldots \ldots \ldots \ldots \ldots \ldots \ldots \ldots \ldots$ 
RECIPIENTS OF THE

JOHN HOWLAND AWARD

(Presented by The American Pediatric Society)

1952 Edwards A. Park

1953 Grover F. Powers

1954 Bela Schick

1955 James L. Gamble

1956 Harold K. Faber

1957 Ethel C. Dunham

1958 Irvin McQuarrie

1959 Daniel C. Darrow

1960 Bronson Crothers

1961 Rustin Mclntosh

1962 Joseph Stokes, Jr.

1963 Lawson Wilkins
1964 Samuel Z. Levine

1965 John Caffey

1966 L. Emmett Holt, Jr.

1967 Martha M. Eliot

1968 Paul Gyorgy

1969 Allan M. Butler

1970 Josef Warkany

1971 Helen B. Taussig

1972 Waldo E. Nelson

1973 Louis K. Diamond

1974 Albert B. Sabin

1975 Harry H. Gordon

1976 Clement A. Smith

1977 A. Ashley Weech 


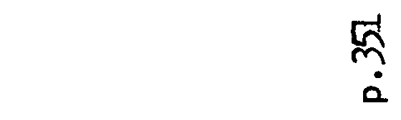

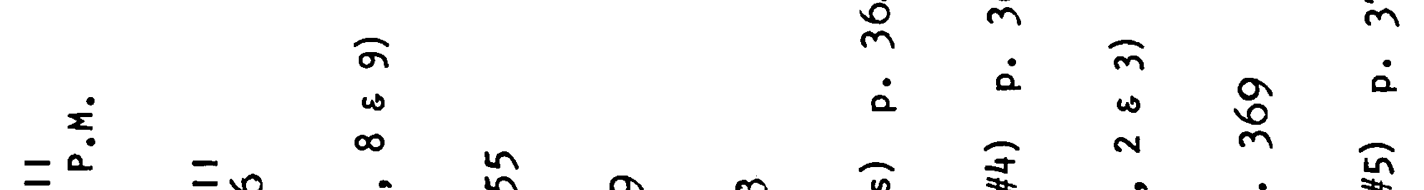

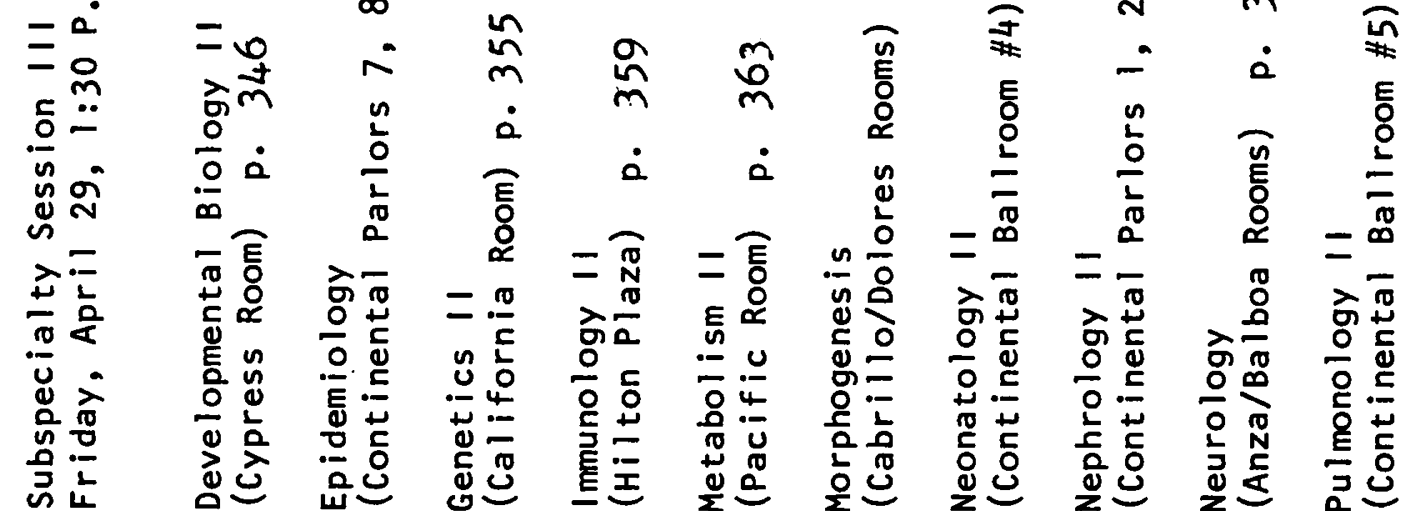

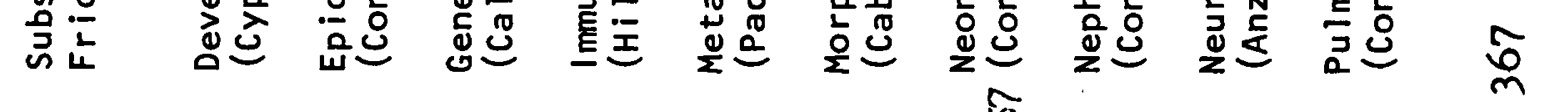

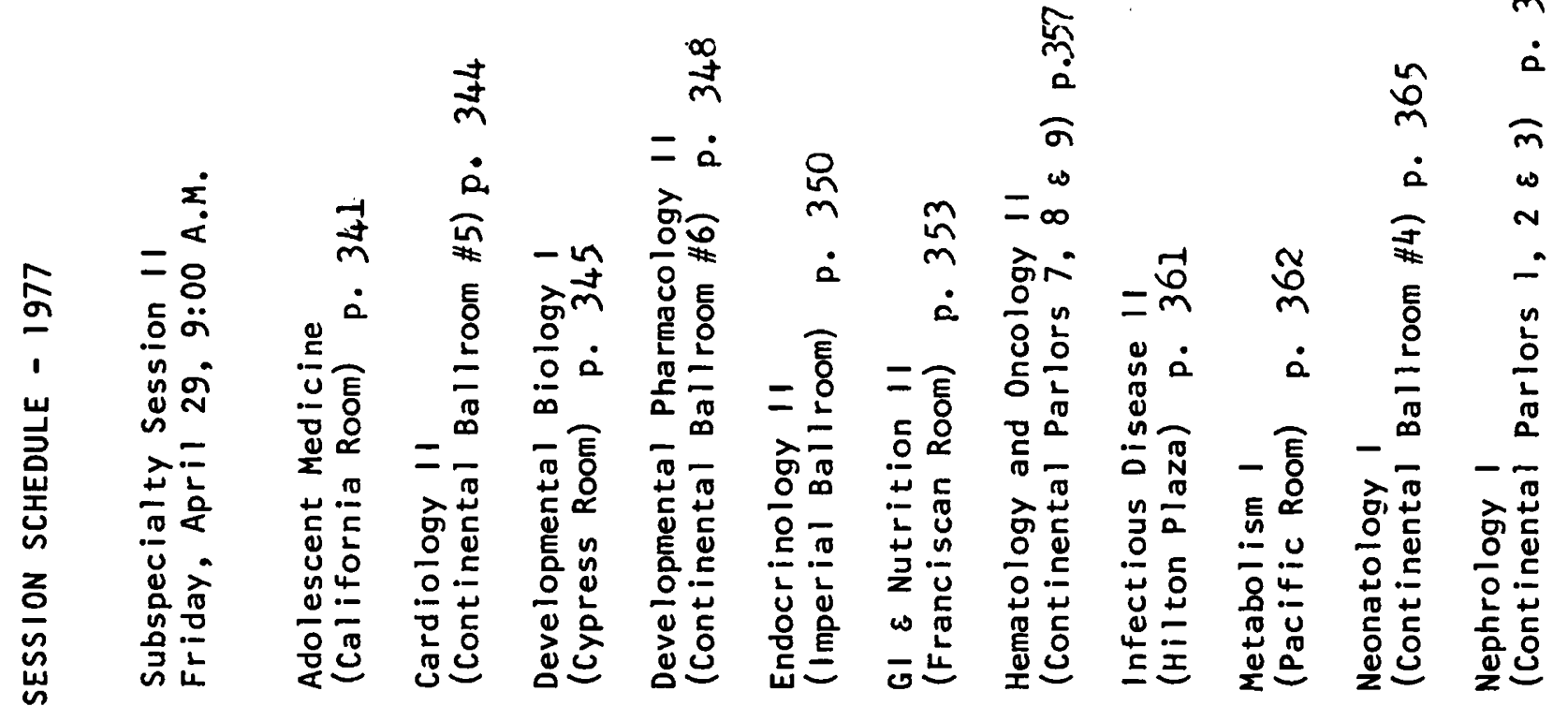

引

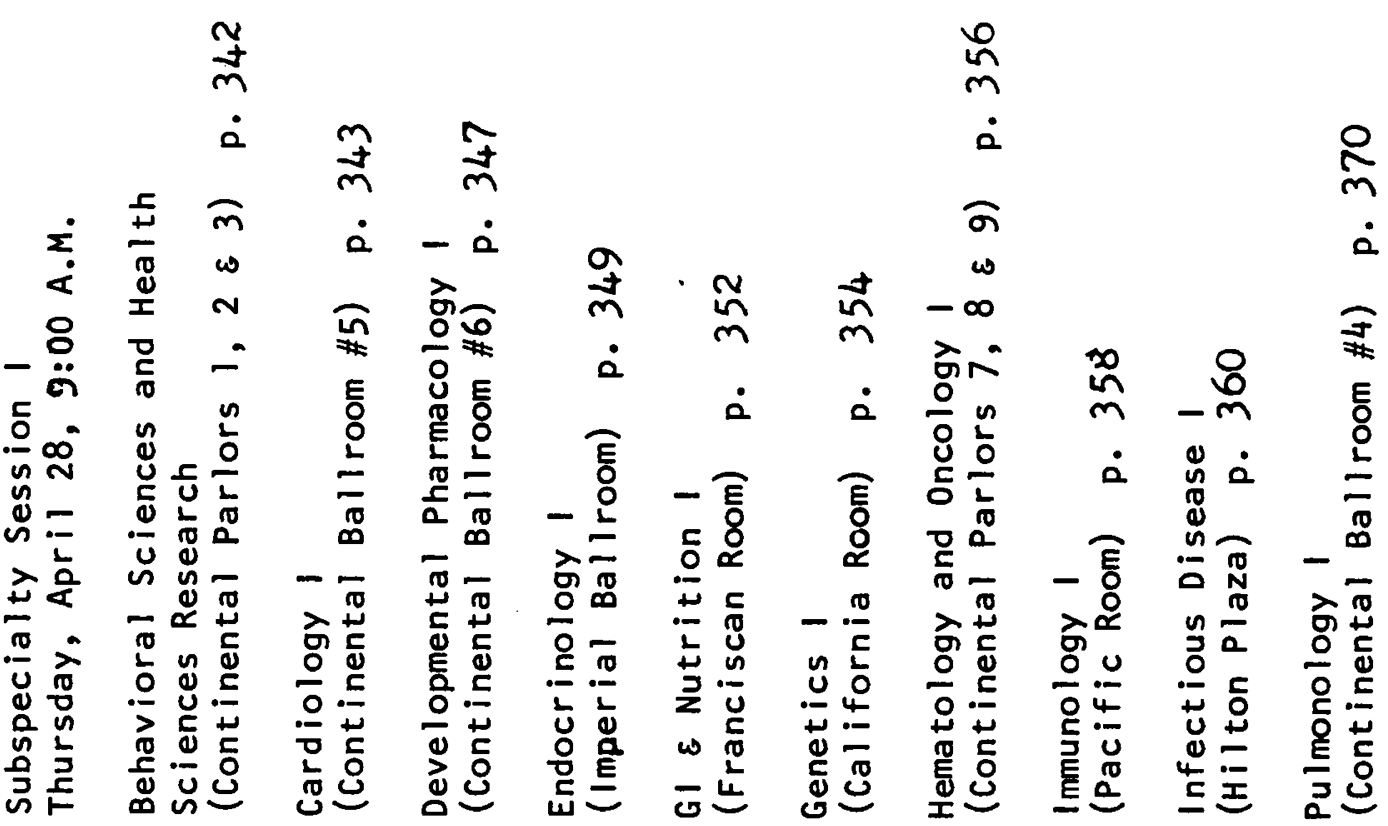




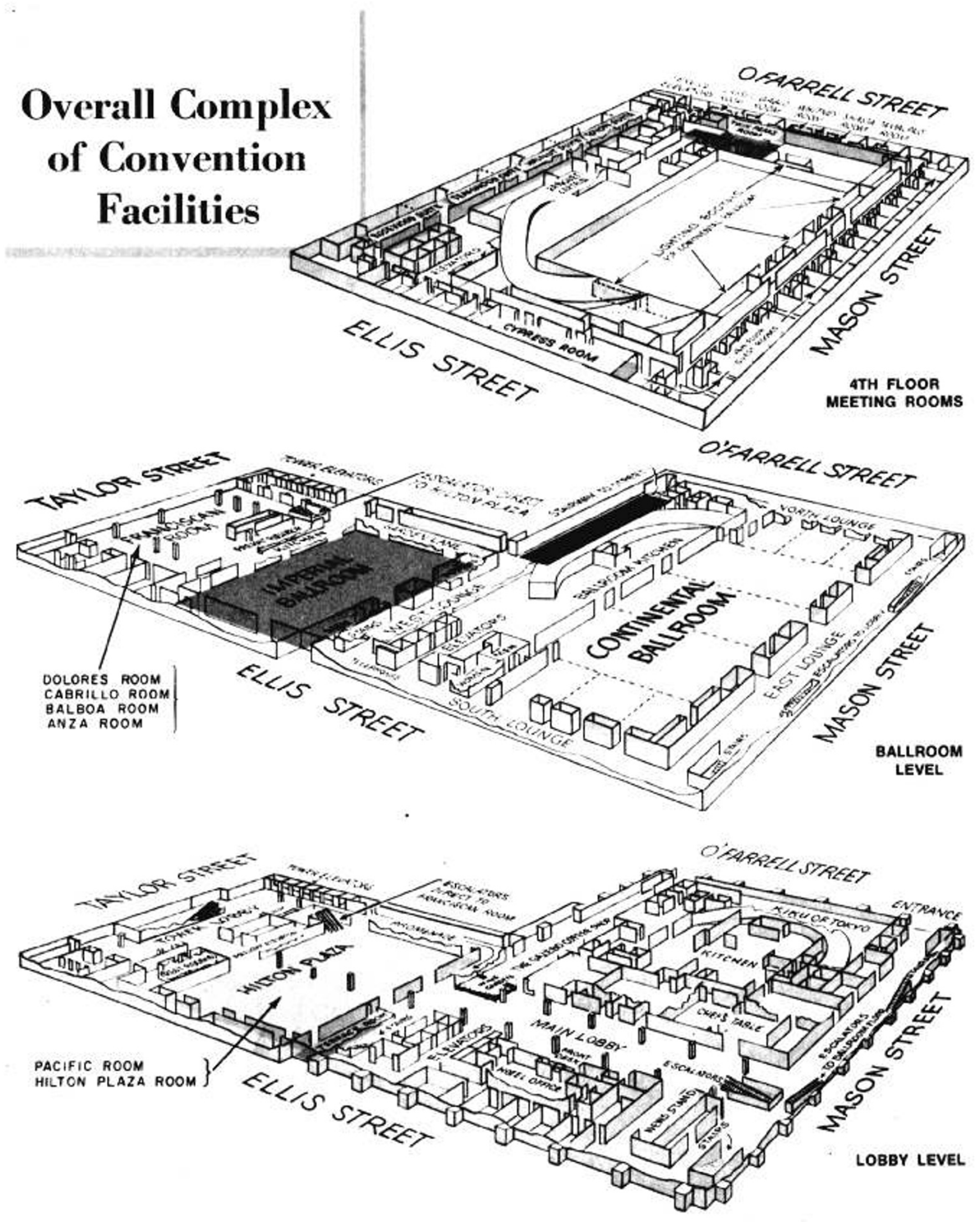


THE AMERICAN PEDIATRIC SOCIETY

\author{
April 27, 1977, 9:00 A.M. \\ Continental Ballroom \\ Presidential Address Margaret H.D. Smith \\ SPECIAL PLENARY SESSIONS \\ MODERATOR: Conrad M. Riley
}

9:30 ISSUES IN BIOMEDICAL ETHICS. Norman Fost, Assistant Professor of Pediatrics and History of Medicine and Director of Program in Medical Ethics, University of Wisconsin, Madison, Wisconsin.

10:00 INTERMISSION

10:15 CHANGING STRUCTURE AND FUNCTIONS OF THE FAMILY AND ITS IMPACT UPON OUR CHILDREN. Albert J. Solnit, M.D., Professor of Pediatrics, Yale University School of Medicine, New Haven, Connecticut.

10:45 THE LAW AND THE CHILD. Robert Mnookin, Professor of Law, University of California School of Law, Berkeley, California.

$11: 15$ TO BE ANNOUNCED

THE AMERICAN PEDIATRIC SOCIETY

April 27, 1977, 1:30 P.M.

Continental Ballroom

PRESENTATION OF THE HOWLAND AWARD TO A. ASHLEY WEECH BY ELIA M. AYOUB

Moderator: Margaret H. D. Smith

2:30 Intermission

SPECIAL PLENARY SESSION

Continental Ballroom

2:45 THE EFFECT OF IMMUNE COMPLEXES ON GOBLET CELL MUCUS RELEASE. A pOSSIble new mechanism of gastrointestinal host defense. W. Allan Walker, Kurt J. Bloch. Harvard Med. School, Mass. Gen. Hosp., Boston, Mass. (747)

3:00 DETECTION OF GASTROESOPHAGEAL REFLUX (GER) IN THE PEDIATRIC AGE PATIENT BY ESOPHAGEAL INTRALUMINAL PH PROBE MEASUREMENT (TUTTLE TEST). Arthur R. Euler, Marvin E. Ament. U. of Calif. Center for the Health Sciences, Dept. of Ped., Los Angeles. (430)

3:15 MUSCLE ULTRASTRUCTURE IN REYE'S SYNDROME (RS): EVIDENCE FOR A MYOPATHY. J. C. Partin, J. S. Partin and W. K. Schubert. Dept. of Ped U. of Cincinnati. (1156)

3:30 PROSTAGLANDINS (PG's) AND THE FETAL DUCTUS ARTERIOSUS (PDA). Stanley E. Kirkpatrick, Morton P. Printz, William F. Friedman. Pediatric Cardiol., U. Calif. at San Diego School of Med. (133) 
3:45 RESPONSE OF THE RENIN-ANGIOTENSIN-ALDOSTERONE SYSTEM TO FUROSEMIDE

AND ACUPE SALT LOADING IN THE FETAL LAMB. Sharon R. Siegel, Rosemary D. Leake,

Delbert A. Fisher. UCLA-Harbor Gen. Hosp., Dept. of Ped., Torrance, (238)

4:00 PROPRANOL ADMINISTRATION IN INFANCY. Carol M. Cottrill, Russell G. McAllister, Jacquel ine A. Noonan, U. of Kentucky College of Med. Dept. of Ped., Lexington. (260)

THE SOCIETY FOR PEDIATRIC RESEARCH

April 28, 1977, 1:45 P.M. Continental Ball room

Presidential Address: $\quad$ Frederick C. Battaglia

COMMONALITY AND DIVERSITY IN FETAL DEVELOPMENT: BRIDGING THE INTERSPECIES GAP.

SPECIAL PLENARY SESSION

Moderator: Frederick C. Battaglia

2:30 AMINO ACID METABOLISM IN SKELETAL MUSCLE. David Kipnis, M.D., Busch Professor of Medicine, Chairman, Department of Internal Medicine, Washington $U$. School of Medicine, St. Louis, Missouri

\section{$3: 15 \quad$ INTERMISSION}

3:30 THE GENETIC DEFICIENCIES IN THE COMPLEMENT SYSTEM. Fred S. Rosen, M.D. Gamble Professor of Pediatrics, Children's Hospital Medical Center, Harvard Medical School, Boston, Mass.

4:15 CONFLICT OVER PEDIATRIC RESEARCH: IS ETHICS HARMFUL TO CHILDREN'IS HEALTH? Albert R. Jonsen, Ph.D., Associated Professor of Bioethics, University of California at San Francisco, Department of Pediatrics, San Francisco, California.

POSTER SESSION

Thursday, April 28, 1977

$10: 30$ - $12: 30$

West Lounge and Garden Lane

Moderators: Michael A. Heymann and Edwin G. Brown

1. CONTINUOUS PULMONARY ARTERY PRESSURE MONITORING IN PERSISTENT PULMONARY HYPERTENSION OF THE NEWBORN. George J. Peckham, William W. Fox, Marta Blesa (Spon. by William J. Rashkind) U. of Pa. Sch. of Med., Dept. of Peds. and The Children's Hosp. of Philadelphia, Philadelphia. (151)

2. A NEW FIBER OPTIC UMBILICAL ARTERIAL CATHETER FOR CONTINUOUS OXYHEMOGLOBIN SATUARATION MEASUREMENT. Andrew R. Wilkinson, George A. Gregory, Roderic H. Phibbs. Cardiovas. Research Inst. and Depts. of Ped. and Anes. U. of California, San Francisco. (1038) 
3. BATH TUB NEAR-DROWNING AS A MANIFESTATION OF THE CHILD NEGLECT SYNDROME: clinical, biochemical and social aspects. Judy Palmer, Daniel V. Schidlow, Nancy N. Huang, Temple U. Sch. Of Med. Dept. of Ped. St. Christopher's Hosp. for Children, Philadelphia. (1231)

4. NEWBORN HEART RATE MONITORED WITHOUT ELECTRODE ATTACHMENT. AndreW J. Macnab (spon. by Sydney Segal) U. of British Columbia, Dept. of Ped., Vancouver (992)

5. COMPARISON OF NON-INVASIVE METHODS OF ESTIMATING OXYGENATION IN INFANTS. Krauss, A.N., Waldman, S., Frayer, W.W., Auld, P.A.M. New York Hosp. Cornell Med. Center, Perinat. Center, New York. (1211)

6. HIGH INCIDENCE OF LUNG PERFORATION BY CHEST TUBE IN NEONATAL PNEUMOTHORAX. Moessinger, A.C., Driscoll, J.M., Jr. Wigger, H.J., (Spon. by Blac, W.A.), Depts. of Peds. \& Path., Columbia U. Coll. of P\& S, N.Y. (1226)

7. GLUCOSE INFUSION FOR THE PREVENTION OF BILIRUBIN TOXICITY IN THE NEONATE: THE ROLE OF FREE FATTY ACIDS (FFA). Enrique M. Ostrea, Jr., Andres E. Bartos, Cheryl A. Fleury, C. Antonio Jesurun. Wayne State U. and Hutzel Hosp. Dept. of Ped. (1005)

8. PERIPHERAL MEDIAN NERVE DAMAGE SECONDARY TO BRACHIAL ARTERIAL BLOOD GAS SAMPLING: Karen E. Page, Dawna L. Armstron, Pamela M. Fitzhardinge. U. of Toronto, Research Inst., Hosp. for Sick Children, Toronto. (1006)

9. ARTERIAL OXYGEN TENSION $\left(\mathrm{PaO}_{2}\right)$ MEASUREMENTS-SAFETY AND ACCURACY OF A NEW CATHETER SENSON. Edwin G. Brown, Chung C. Liu, Francis E. McDonnell, Avron Y. Sweet, Sidney K. Wolfson. Dept. of Ped. Mt. Sinai School of Med., New York, and Dept. of Surgery and Chemical Engineering, U. Of Pitts. Pittsburgh. (1181)

10. SKIN SENSORS FOR MONITORING OXYGEN TENSION OF NEWBORNS. Wolfgang F. H. Mindt and Patrick Eberhard (Spon. by Avron $Y$. Sweet). F. Hoffmann-La Roche $\varepsilon$ Co., A.G., Dept. of Bio-Elec. Basle, Switzerland (1225)

11. DESIGN OF DUAL ELEMENT SENSORS, ELECTRONIC SYSTEMS AND CALIBRATORS FOR THE TRANSCUTANEOUS MEASUREMENT OF $\mathrm{PCO}_{2}$ Robert A. Macur, Ponthenkandath Sasidharan John P. Grausz, Spon. by Frederick M. Blodgett, Med. Coll. of Wisconsin, Milwaukee County Med. Complex. Dept. of Ped. Milwaukee. (1217)

12. A SIMPLIFIED ASSESSMENT OF GESTATIONAL AGE. Jeanne L. Ballard, Kathy Kasmaier, Marshall Driver, (Spon. by Irwin J. Light), U. of Cincinnati Coll. of Med. (16)

13. DEVICE FOR INDIRECT MEASUREMENT OF MEAN ARTERIAL PRESSURE Maynard Ramsey III John S. Curron (Spon. by Lewis A. Barness) Applied Med. Research Corp. Tampa. U. of South Florida Coll. of Med. Dept. of Ped. Tampa. (1015)

14. INSULIN RELEASE DURING ACUTE AND CHRONIC hYPOXIA. David Baum, Randall. Griepp, Daniel Porte, Jr., Stanford Med. Ctr. \& U. of Washington Stanford, Seattle(836) 


\section{THE AMERICAN PEDIATRIC SOCIETY \\ and \\ THE SOCIETY FOR PEDIATRIC RESEARCH \\ SUBSPECIALTY SESSIONS}

April 28 and 29, 1977

Adolescent Medicine

April 29, 1977, 9:00 A.M.

California Room

Moderators: Felix P. Head and Michael 1. Cohen

1. 9:00 EFFECTS OF CYCLIC ESTROGENS ON PREPUBERTAL \& PUBERTAL GIRLS WITH EXCESSIVE HEIGHT. M. James Whitelaw and William H. Graham, Dept. of Endocrinology $\&$ Radiology, O'Connor Hospital, San Jose, California. (Spon. by Philip Sunshine) (8)

2. 9:15 MEDICAL MANAGEMENT OF CROHN'S DISEASE IN ADOLESCENCE. Whitington, Peter F., Barnes, H. Verdain, Bayless, Theodore M.. (Spon. by Odell, Gerard B.). Johns Hopkins U. Sch. of Med., The Johns Hopkins Hosp. Depts. of Med. and Ped. Baltimore. (9)

3. 9:30 EFFECT OF ETHANOI. (ETOH) DURING PUBERTAL GROWTH SPURT (PGS) ON GROWTH OF RATS. David M. Namerow, Lois M. Roeder, S. Michael Plaut, Felix P. Heald, U. of Maryland Sch. of Med., Depts. of Ped. and Psych., Baltimore. (5)

4. 9:45 INFANT REARING ATTITUDES OF ADOLESCENT MOTHERS. Zuckerman, Barry S., Winsmore, G. K., Alpert, Joel J., Boston U. Sch. of Med., Boston City Hosp. Dept. of Ped. Boston. (12)

5. 10:00 SELF PERCEPTION IN OBESE ADOLECENTS AS MEASURED BY HUMAN FIGURE DRAWINGS, Ronald Shenker, Marsha Sonnenblick, Vincent Fisichelli, (Spon. by Philip Lanzkowsky) Sch. of Med., Health Sciences Ctr. State Univ. of N.Y. at Stony Brook, Long Island Jewish-Hillside Med. Ctr., Dept. of Ped., New Hyde Park. (6)

\section{0:15 INTERMISSION}

6. 10:30 HEMODYNAMIC (HD) FEATURES OF HYPERTENSION AMONG HIGH SCHOOL STUDENTS. A. Hernandez, D. Goldring, S. Choi, S. Londe, M. Sivakoff and C. Britton. Washington U. Sch. of Med. Dept. of Ped., St. Louis.

7. 10:45 NEPHROTIC SYNDROME IN THE SECOND DECADE OF LIFE. Ingelfinger, Julie R. Dept. of Ped. Children's Hospital Medical Center, Boston. (Spon by Grupe, Warren) (3)

8. 11:00 A ROLE FOR LAPAROSCOPY IN THE MANAGEMENT OF ADOLESCENTS WITH CHRONIC SALPINGITIS. K. Hein, S. Kleinhaus, M. Mayer, M. I. Cohen, I. F. Litt, Albert Einstein Coll. Med., Montefiore Hosp. and Med. Ctr., Dept. Ped. \& Surg., The Bronx. (1)

9. 11:15 AN EVALUATION OF A GENETIC SCREENING PROGRAM FOR THALASSEMIA TRAIT IN GREEK ADOLESCENT POPULATION. C.F. Mann, W.R. Anyan, H.A. Pearson, Yale U. Sch. Of Med., Yale New Haven Hsopital, Dept.of Ped., New Haven.

(4) 


\section{BEHAVIORAL SCIENCES AND HEALTH SCIENCES RESEARCH \\ April 28, 1977, 9;00 A.M.}

Continental Parlors 1,2, $\& 3$

Moderators: T. Berry Brazelton and Bonnie W. Camp

1. 9:00 NALOXONE REVERSAL OF MILD NEUROBEHAVIORAL DEPRESSION IN NORMAL NEWBORNS AFTER ROUTINE OBSTETRICAL ANALGENSIA. Virginia Williams, Bedford W. Bonta, Jeryl V. Gagliardi, Joseph B. Warshaw, Yale U. Sch. of Med. Dept. of Ped. New Haven. (77)

2. 9:15 NEUROBEHAVIORAL ASSESSMENT OF HIGH-RISK NEONATES. Cecelia Daum, Diane Kurtzberg, Bruce Grellong, Susan Albin and Herbert Vaughan (spon. by Lawrence Gartner), Depts. of Ped. Neuroscience and Psychiatry, Albert Einstein Coll. of Med. Bronx. (28)

3. 9:30 POST-PARTUM EXTENDED MATERNAL-INFANT CONTACT: SUBSEQUENT MOTHERING AND CHILD HEALTH. Susan M. O'Connor, Peter M. Vietze, John B. Hopkins, William A. Altemeier. Vanderbilt U. Nashville General Hosp. Dept. of Ped. and Peabody Coll. for Teachers, Dept. of Psychol., Nashville. (52)

4. 9:45 BEHAVIORAL DIALOGUES BETWEEN MOTHERS AND INFANTS: THE EFFECT OF PREMATURITY Josephine V. Brown, Roger Bakeman. Emory U. Sch. of Med. Dept. of Ped. Georgia State U. Dept. of Psychol., Atlanta. (Spon. by Richard W. Blumberg) (22)

5. 10:00 A BIRTH IN THE HOSPITAL: THE EFFECT ON THE SIBLING. Mary Anne Trause, Michelle Boslett, Diana Voos, Carolyn Rudd, John Kennel, Marshall Klaus. Case Western Reserve U. Dept. of Ped., Cleveland (70)

\section{0:15 INTERMISSION}

6. 10:30 EARLY HOME INTERVENTION TO IMPROVE MOTHERING OF PREMATURES. Richard Umansky, Rosamund Gardner. Children's Hosp. Med. Ctr. Oakland. (Spon. by Bertram Lubin) (72)

7. 10:45 EFFECT OF EARLY ADOPTION ON I.Q. AND SCHOOL PERFORMANCE OF MAL NOURISHED CHILDREN. Myron Winick, My Lien Nguyen, Knarig K. Meyer and Ruth C. Harris. Columbia U. Coll. of Physicians and Surgeons, Institute of Human Nutrition, New York City. (79)

8. 11:00 THE EFFECTS OF THERAPY ON THE DEVELOPMENTAL SCORES OF IRON DEFICIENT INFANTS. Frank A. Oski and Alice M. Honig. SUNY, Upstate Med. Ctr. and the Coll. of Human Development, Syracuse U. Syracuse. (53)

9. 11:15 THE EFFECT OF STRESS ON CHILDREN'S DRAWINGS. Raymond A. Sturner, Fred Rothbaum, John Wolfer, Madaline Visintainer. (Spon. by Samuel L. Katz). Duke U. Med. Ctr., Dept. of Ped. Durham, N.C.; Yale U. Med. Ctr., New Haven (67)

10. 11:30 ANALYSIS OF PSYCHOSOCIAL ASPECTS OF INTERNSHIP. Edwenna R. Werner, Robert Adler, Ricki G. Robinson, Carl M. Grushkin, Barbara M. Korsch. Children's Hosp. of Los Angeles. (76). 
CARDIOLOGY

First Session

April 28, 1977, 9:00 A.M.

Continental Ballroom \#5

Moderators: Ira H. Gessner and Page A.W. Anderson

1. 9:00 PROSTAGLADIN E-1 (PGE-1) and PULMONARY VASCULAR RESISTANCE IN NEONATAL LAMBS. M.E. Tripp, M.A. Heyman, A.M. Rudolph. Cardiovascular Research Institute, U. of Calif. San Francisco. (180)

2. 9:15 RENAL VASCULAR PROTECTION BY PROSTAGLANDINS DURING HYPOXEMIA IN UNANESTHETIZED FETAL LAMB. Ronald W. Millard, Hank Baig, Stephen Vatner (Spon.

Alexander Nadas). Harvard Med. Sch., Children's Hosp. Med. Ctr. Dept. of Cardiology Boston. (144)

3. 9:30 MORPHOLOGIC ANALYSIS OF THE PULMONARY VASCULAR BED (PVB) IN INFANTS WITH IN UTERO EXPOSURE TO PROSTAGLANDIN INHIBITORS. Daniel Levin, David Fixler, Frances Morriss, Jon Tyson. U. Tex. Health Science Ctr. Dept. Of Ped., Dallas. (139)

4. 9:45 NON-INVASIVE ESTIMATION OF LEFT TO RIGHT SHUNTS USING ECHOCARDIOGRAM AND RADIONUCLIDE ANGIOCARDIOGRAPHY. Terrence Dillon, Michael J. Gelfand, James Breitweser, Richard A. Meyer, Samuel Kaplan. Cincinnati College of Med. Div. of Cardiology and Radioisotope Lab. Children's Hosp. Med. Ctr. Dept. of Ped. Cincinnati (101)

5. 10:00 RANGE-GATED PULSED DOPPLER ECHOCARDIOGRAPHY: ITS ROLE IN DETECTING DUCTAL SHUNTING IN PREMATURE INFANTS. Robert Solinger, Larry Cook, John Gattinella Francisco Elbl., U. of Louisville Sch. of Med., Dept. of Ped. Div. of Cardiology and Neonatal Med. Louisville. (172)

\section{0:15 INTERMISSION}

6. 10:30 SINUS NODE DYSFUNCTION IN CHILDREN. Steven M. Yabek, (Spon. by Robert E. Greenberg). Dept. of Ped. UNM Sch. of Med. Albuquerque. (187)

7. 10:45 DIAGNOSTIC EVALUATION OF CREATINE KINASE ISOENZYMES IN CHILDREN. Carmelita V. Britton, Antonio Hernandez, Robert Roberts. (Spon. by David Goldring). Washington U. St. Louis Children's Hosp., Dept.. of Ped. and Med. St. Louis (88)

8. 11:00 ELEVATED CREATININE PHOSPHOKINASE-MYOCARDIAL BOUND FRACTION (CPK-MB) AND PAPILLARY MUSCLE INFRACTION IN STRESSED NEWBORNS SHOWING MYOCARDIAL DYSFUNCTION WITH TRANSIENT TRICUSPID INSUFFIENCY (MD with TTI). R. Bucciarelli, R. Nelson, E. Egan, D. Eitzman, I. Gessner. Dept. of Ped. U. of Florida, College of Med. Gainesville. (89)

9. 11:15 ONTOGENESIS OF AUTONOMIC INNERVATION IN MAMMALIAN MYOCARDIUM. WiIIIam J. Marvin, Jr., Robert Roskoski, Jr., R. Kent Hermsmeyer. (Spon. by R.M. Lauer) U. of lowa, Coll. of Med. Dept. of Ped. Biochemistry and Pharmacology, lowa City. (140)

10. 11:30 CATECHOLAMINE EFFECT ON THE FORCE-INTERVAL RELATIONSHIP. Page A.W. Anderson Andres Manring, Edward A. Johnson. Duke U. Sch. of Med., Duke U. Med. Ctr., Dept. of Ped. Durham. (85) 


\title{
CARDIOLOGY
}

\author{
Second Session \\ April 29, 1977, 9:00 A.M. \\ Continental Ballroom\#5
}

Moderators: Ira H. Gessner and Page A. W. Anderson

1. 9:00 THE ECHOCARDIOGRAPHIC FEATURES OF CONGENTIAL MITRAL STENOSIS. David J. Driscoll, Howard P. Gutgese II, Dan G. McNamara, Baylor Coll. of Med. and Texas Children's Hosp. Dept. of Ped. Houston. (104)

2. 9:15 SERIAL ECHOCARDIOGRAPHIC (ECHO) PROFILES IN INFANTS WITH COARCTATION OF THE AORTA, (COARCT), William A. Findlay, Jennifer P. Wing, David J. Sahn, Stanley J. Goldberg, Gail McDonald, Hugh D. Allen. Dept. of Ped. U. of Arizona Health Seciences Ctr., Tucson (109)

3. 9:30 HYPERTENSION IN COARCTATION OF THE AORTA. Bruce S. Alpert, Hugh H. Bain J. William Balfe, Peter M. Olley, Lanford Kidd. The Hosp. for Sick Children, Dept. of Ped., Toronto, Canada. (83)

4. 9:45 CARDIAC HYPERTROPHY IN YOUNG SPONTANEOUSLY HYPERTENSIVE RATS BEFORE THE ONSET OF HYPERTENSION. Anthony F. Cutilletta, Walter S. Culpepper, Meredith Benjamin, Suzanne Oparil., U. of Chg., Wyler Children's Hosp. Dept. of Ped. Chicago. (97)

5. 10:00 SPECTRUM OF EXERCISE RESPONSES IN CHILDREN WITH AORTIC STENOSIS, Frederick W. James, Samuel Kaplan, U. of Cin. Coll. of Med. Children's Hosp. Med. Ctr. Dept. of Ped., Cincinnati. (129)

\section{$10: 15$ INTERMISSION}

6. 10:30 MYOCARDIAL BIOPSY IN INFANCY AND CHILDHOOD: MODIFIED SMOOTH MUSCLE CELLS IN ENDOCARDIAL ELASTOMYOFIBROSIS. Masahiro Fujita, Harry B. Neustein, Paul R. Lurie. U. of Souther Calif. Sch. of Med. and Children's Hosp. of Los Angeles, Depts. of Path. and Ped., Los Angeles. (112)

7. 10:45 LYMPHOCYTE CYTOTOXICITY TO CARDIAC FIBROBLASTS IN RHEUMATIC CARDITIS Jack H. Hutto, Elia M. Ayoub. Dept. of Ped. U. of Florida, Gainesville. (128)

8. 11:00 POLYCYTHEMIA, CARDIAC OUTPUT AND CORONARY BLOOD FLOW. JUlien 1. E. Hoffman, Adrianta Surjadhana, Lawrence E. Boerboom, and Jacques Rouleau. U. of California, Sch. of Med. Dept. of Ped. and Cardiovascular Research Institute San Francisco. (126)

9. $11: 15$ REGIONAL BLOOD FLOW IN POLYCYTHEMIA AND HYPERVOLEMIA. U.R. Kotagal, W. J. Keenan, J.H. Reuter, J.J. Steichen, L. I. Kleinman. U. of Cincinnati, College of Medicine, Dept. of Ped., Cincinnati. (135)

10. 11:30 MYOCARDIAL HYPOXIA DURING ISOPROTERENOL INFUSION IN AN ANIMAL MODEL: POSSIBLE CAUSE OF MYOCARDIAL DYSFUNCTION IN CYANOTIC CONGENITAL HEART DISEASE. Thomas P. Graham, Jr., Glenn 3. Buckspan, R. Darryl Fisher. Div. of Ped. Cardiology, Vanderbilt U. Nashville. (124) 
DEVELOPMENTAL BIOLOGY

First Session

April 29, 1977, 9:00 A.M.

Cypress Room

Moderators: Delbert A. Fisher and Peter Adam

1. 9:00 THIRD TRIMESTER DEVELOPMENT OF SMALL INTESTINAL ENTEROKINASE (EK) AND DISACCHARIDASE ACTIVITIES IN THE HUMAN FETUS. E. Lebenthal, I. Antonowicz. Harvard Med. Sch. Children's Hosp. Med. Ctr., Dept. of Ped., Boston (220)

2. 9:15 EFFECT OF COLOSTRUM ON GROWTH OF INTESTINAL MUCOSA. Wm.C. Heird, I.H. Hansen. Columbia U. Coll. of Phys. E Surgeons, Dept. of Ped., N.Y. (210)

3. 9:30 EPIDERMAL GROWTH FACTOR (EGF): BINDING CHARACTERISTICS AND GROWTH RESPONSE OF NORMAL AND VIRALLY TRANSFORMED MOUSE FIBROBLASTS. Carmen Brutico, R. Ladda, Penn. State U. Coll. Med. M.S. Hershey Med. Ctr., Dept. of Ped., Hershey. (193)

4. 9:45 MESSENGER RNA TRANSCRIPTION IN REGENERATING KIDNEY. W.L. Miller, B.J. McCarthy, (Spon. by M.M. Grumbach), U. of Calif., San Francisco, Depts. of Biochemistry and Biophys and Ped., San Francisco. (228)

5. 10:00 RELATION OF THYMIDYLATE SYNTHETASE (TS) ACTIVITY IN DNA ACCUMULATION RATE IN DEVELOPING RAT CEREBELLUM: EFFECT OF HYPER- AND HYPOTHYROIDISM. B.R. Clark, M.E. Weichsel, Jr., UCLA Sch. of Med. Harbor fien. Hosp., Depts. of Pys and Ped., Torrance. (195)

\section{0:15 INTERMISSION}

6. 10:30 MORPHOLOGICAL AND FUNCTIONAL CORRELATES OF SYNCHRONOUS BEATING BETWEEN EMBRYONIC HEART CELL AGGREGATES AND LAYERS. E.B. Griepp, J.P. Revel, J.H. Peacock, M.R. Bernfield. Stan. U. Sch. of Med., Depts. of Ped and Neur., Stanford and Calif. Inst. of Tech., Div. of Biology, Pasadena. (205)

7. 10:45 FATAL PLACENTAL INFARCTION, A PROSPECTIVE STUDY. R.L. Naeye. (Spon. by N.M. Nelson). Penn. State U. Coll. of Med., M.S. Hershey, Med. Ctr. Dept. of Path., Hershey. (229)

8. 11:00 ELEVATED CORD BLOOD FREE ERYTHROCYTE PORPHYRIN (FEP) - A SIGN OF "MASKED" IRON DEFICIENCY? M.A. Gottuso, B.F. Oski and F.A. Oski, SUNY, Upstate Med. Ctr., Syracuse. (203)

9. 11:15 NEONATAL TYROSINEMIA (NT) IN THE ESKIMO. RESULT OF A PROTEIN POLYMORPHISM? C.R. Scriver, T. Perry, Jr., L. Lasley, C.L. Clow, D. Coulter, C. Laberge. Dept. of Ped., McGill U. Montreal; Quebec Network of Genetic Med., and Frobisher Bay General Hosp., NWT, Canada. (237)

10. 11:30 WHITE ADIPOSE TISSUE (WAT) AND HEAT PRODUCTION IN THE NEWBORN RABBIT. T. Hiem, H. Schenk, F. Varga, E. Goetze. (Spon. by D. Fraser). Res. Inst., Hosp. for Sick Children, U. of Toronto, Dept. of Ped., U. Med. Sch. Pecs, Hungary and Inst. of Pathophysiol., U. Jena, German Democratic Republic. (209) 
DEVELOPMENTAL B IOLOGY

Second Session

April 29, 1977, 1:30 P.M.

Cypress Room

Moderators: Delbert A. Fisher and Peter Adam

1. 1:30 POSTNATAL CHANGES IN OXYGEN TRANSPORT: RELATIONSHIP BETWEEN CARDIAC OUTPUT ( $\mathrm{CO}), \mathrm{O}_{2}$ CONSUMPTION $\left(\mathrm{V}_{2}\right)$, and $\mathrm{O}_{2}$ CARRYING CAPACITY (CAP). George Lister, Thomas K. Walter, Abraham M. Rudolph, and Peter R. Dallman. Med. Ctr. Dept. of Ped., San Francisco. (221)

2. 1:45 EFFECT OF INTRAUTERINE HYPOXIA ON MITOCHONDRIAL RESPIRATORY ACTIVITY OF THE FETAL LAMB. Maria Delivoria-Papadopoulos, Leena Mela, James D. Ferguson, Leonard D. Miller. U. of Penn. School of Med. Depts. of Physiology, Ped., Surgery Philadelphia. (198)

3. 2:00 INCREASES IN BRAIN GLUCOSE AND PLASMA GLUCOSE, GLYCEROL AND B-HYDROXYBUTYRATE AFTER AMINOPHYLLINE. Jean Holowach Thurston, Richard E. Hauhart, and John A. Dirgo. Dept. of Ped., Wash. U. Med. Sch. St. Louis. (246)

4. 2:15 MATERNAL ACIDOSIS AND FETAL GROWTH RETARDATION. Peggy Rapoport, Yoshio Miyazaki, David Bolam, Charles L. Paxson Jr., (Spon. by G. C. Rosenquist) U. of Nebraska Coll. of Med. Omaha. (232)

5. 2:30 TRANSFER OF LEUCINE AND GLUTANATE ACROSS HUMAN PLACENTA. Henning Schneider, Jean-Claude Challier, Karlheinz Mohlen, Joseph Dancis. Frauenklinik, Marburg, W. Germany, U. Pierre et Marie Curie, Paris, France, U. Frauenklinik, Munster, Germany, NYU Sch. of Med. Dept. of Ped. New York City. (236)

\section{2:45 INTERMISSION}

6. 3:00 AMMONIA PRODUCTION BY THE PREGNANT SHEEP UTERUS. I.R. HOlzman, J.A. Lemons, G. Meschia, F.C. Battaglia. U. of Colorado Med. Ctr., Div. of Perinatal Med., Denver. (214)

7. 3:15 MATERNO-FETAL TRANSFER AND UPTAKE OF 2-DEOXY-GLUCOSE (DG) AND $\alpha$-AMINOISOBUTYRIC ACID (AIB) IN INTRUATERINE GROWTH RETARDATION (IUR) ASSOCIATED WITH RESTRICTED UTERINE BLOOD SUPPLY. M. Nitzan, S. Orloff, J. D. Schulman. NICHD, NIH, Bethesda. (230)

8. 3:30 MATERNAL FETAL OSMOLAR HOMEOSTASIS: FETAL POSTERIOR PITUITARY AUTONOMY. Rosemary D. Leake, Richard E. Weitzman, Delbert A. Fisher. Depts., of Ped. Med. UCLA-Harbor General Hospital, Torrance. (219)

9. 3:45 VASOPRESSION RELEASE IN LAMB FETUS. Fred G. Smith, Richard Weitzman, Jean Robillard, Allen Erenberg, and Delbert Fisher, U. of lowa, lowa City and UCLA-Harbor General Hosp. Torrance, Calif. Depts of Ped. (241)

10. 4:00 THE PITUITARY ADRENAL RESPONSE TO HEMORRHAGIC STRESS OF LAMB FETUSES IN UTERO. A. A. Macdonald, J. Rose, M.A. Heyman, A. M. Rudolph., U. of Calif., Depts. of Ped., Physiology, and Ob-Gyn and C.V.R.I., San Francisco (223) 


\section{DEVELOPMENTAL PHARMACOLOGY}

First Session

April 28, 1977, 9:00 A.M. Continental Ball room \# 6

Moderators: Sydney Segal and Allen H. Neims

1. 9:00 DRUG UTILIZATION DURING THE PERINATAL PERIOD. R.M. Hill, J.P. Craig, M.D. Chaney, L.M. Tennyson, L.B. McCulley. Baylor Coll. of Med., Dept. of Ped., Houston. (273)

2. 9:15 CENTRAL NERVOUS SYSTEM LEVELS OF CHLORAMPHENICOL IN PREMATURE INFANTS. L.M. Dunkel, (Spon. by A.E. McElfresh), St. Louis U. School of Med. Cardinal Glennon Memorial Hosp. for Children, Dept. of Ped., St. Louis. (267)

3. 9:30 THE RELATIONSHIP OF AGE TO THE DISTRIBUTION AND PHYSIOLOGIC EFFECTS OF DIGOXIN IN SHEEP. W. Berman, Jr., P.J. Ravenscroft, L.B. Sheiner, M.A. Heymann, K.L. Melmon, A.M. Rudolph, U. Cal. SF, Dept. Ped. and Clinical Pharm. and Hershey Medical Center, Dept. Ped. (255)

4. 9:45 STUDIES OF THE ANTIMITOTIC EFFECTS OF CARDIAC GLYCOSIDES: MOLECULAR FEATURES AND POTENCY. B.R. Gordon, G.B. Segel, M.A. Lichtman, Depts. of Ped. $\varepsilon$ Med, , U. of Roch. Sch. of Med., Rochester, N.Y. (298)

5. 10:00 PLASMA AND BRAIN LEVELS OF PHENOBARBITAL AND DIPHENYLHYDANTOIN IN NEONATES WITH SEIZURES. G.S. Carter, M.J. Painter, C. Pippinger (Spon. by T.P. Foley, Jr.) U. of Pitts. Magee Womens Hosp., Children's Hosp. of Pitts., Dept. of Ped., Pitts., and Columbia Presbyterian U., Neurological Institute of N.Y. (258)

$$
\text { 10:15 INTERMISSION }
$$

6. 10:30 DECREASED HYPOXIC, HYPEROXIC AND BRADYCARDIC EPISODES AS RESPONSES OF NEONATES TO THEOPHYLLINE. J.L. Peabody, A.L. Neese, J.F. Lucey, A.G.S. Philip, L.F. Soyka, U. of Vermont Coll. of Med. Depts. of Ped. and Pharm., Burlington. (288)

7. 10:45 PHARMACOKINETIC DISPOSITION OF CAFFEINE IN PREMATURE NEONATES WITH APNEA. J.V. ARANDA, W. Gorman, E.W. Outerbridge, A.H. Neims. Dept. of Newborn Med., Montreal Children's Hosp. and Roche Dev. Pharmacology Unit, McGill U. Montreal. (254)

8. 11:00 TREATMENT AND FOLLOW-UP OF NEONATAL MEPIVACAINE INTOXICATION. L.S. Hillman, R.E. Hillman, W.E. Dodson, Washington U. Sch. of Med., St. Louis Children's Hosp., Dept. of Ped., St. Louis. (275)

9. 11:15 MAGNESIUM LEVELS IN INFANTS OF MOTHERS TREATED WITH MgSO4. B.C. Dangman, T.S. Rosen, (Spon. by L.S. James), Dept. of Ped., Coll. of P. E S., Col. U., New York. (262)

10. 11:30 LETHAL AND SUBLETHAL EFFECTS ON THE PROGENY OF MALE RATS TREATED WITH METHADONE. L.F. Soyka, J.M. Peterson, J.M. Joffe, U. of Vermont Coll. of Med. Dept. of Pharmacology, Burlington. (302) 


\section{DEVELOPMENTAL PHARMACOLOGY}

Second Session

April 29, 1977, 9:00 A.M. Continental Ball room \#6

Moderators: Sydney Segal and Allen H. Neims

1. 9:00 AEROSOLIZED GENTAMICIN IN CYSTIC FIBROSIS: M. A. Danish, A. Arbeter, M. Rosenlund. S. J. Yaffe. U. of Penn. Sch. of Med., Children's Hosp. of Phil. Dept. of Ped. Philadelphia. (263)

2. 9:15 HIGH INCIDENCE OF GENERALIZED EXANTHEM IN EPILEPTIC CHILDREN AND ITS RELATION TO PLASMA LEVELS OF PHENYTOIN. W. J. T. Rane, A. Hojer, B. Thomson, G. Sjoqvist, F. Karolinska, Institute, Huddinge, Hosp. Dept. Clinical Pharmacology, Stockholm. (306)

3. 9:30 CHRONIC PHENOBARBITAL ADMINISTRATION DURING INFANCY: EFFECTS UPON BRAIN DEVELOPMENT IN RATS. J.Diaz, R. J. Schain., U. of Calif. Depts. of Psychiatry, Neurology and Ped., Los Angeles. (264)

4. 9:45 HYDROCHLOROTHIAZIDE (HCT) THERAPY IN HYPERTENSIVE (HT) AND RENAL INSUFFICIENT (RI) CHILDREN: ELIMINATION KINETICS AND METABOLIC EFFECTS. B. Mirkin, A. Sinaiko, M. Cooper, M. Anders. U. of Minnesota, Div. Clinical Pharmacology, Minneapolis (281)

5. 10:00 THE METABOLISM OF LEAD (Pb) IN THYROPARATHYROIDECTOMIZED (TPTX) RATS AFTER INFUSIONS WITH CaNa ${ }_{2}$ EDTA (EDTA) AND PARATHYROID HORMONE (PTH). J. F. ROSEn E. Wexler, S. Jenks, Albert Einstein Coll. Med., Montefiore Hosp. $\varepsilon$ Med. Ctr. Dept. of Ped., The Bronx. (295)

\section{0:15 INTERMISSION}

6. 10:30 METHYMERCURY EXCRETION: DEVELOPMENTAL CHANGES IN MOUSE AND MAN. R. A. Doherty, A.H. Gates, T.D. Landry, Depts. Ped. E Obstetrics Radiation Biology/ Biophysics; U. of Rochester, Rochester (265)

7. 10:45 AMINOGLYCOSIDE NEPHROTOXICITY, P. S. Lietman, Johns Hopkins U. Sch. of Med. Dept. of Ped., Baltimore, (278)

8. 11:00 MULTIPLICITY OF CYTOCHROMES P-450 DURING DEVELOPMENT. D. K. Manchester, A. H. Neims. Roche Dev. Pharmacology Unit, McGill, Montreal. (279)

9. 11:15 ALTERATION OF HUMAN DRUG METABOLISM BY GROWTH HORMONE. G. P. Redmond, J. J. Bell, J. Perel, Columbia U. Coll. of Physicians and Surgeons, Dept. of Ped., NY (291)

10. $11: 30$ HYPTOENSIVE EFFECT OF DIAZEPAM IN SPONTANEOUSLY HYPERTENSIVE RATS (SHR) R. M. Schieken, M. J. Brody, (Spon. by R. M. Lauer). U. of lowa, Coll. of Med. Dept. of Ped and Pharmacology, Iowa City.

(297) 


\author{
ENDOCRINOLOGY \\ First Session \\ April 28, 1977, 9:00 A.M. \\ Imperial Ballroom
}

Moderators: Claude J. Migeon and Robert P. Kelch

1. 9:00 NEONATAL HYPOTHYROIDISM DETECTED BY THE OREGON REGIONAL SCREENING PROGRAM. S. H. LaFranchi, W. H. Murphey, N. R. M. Buist, P. Reed Larsen, T. P. Foley, Jr. U. of Oregon Sch. of Med., Dept. of Ped. Portland, Public Heal th Lab., Portland, Harvard Med. Sch. Dept. Boston, Children's Hosp., Pittsburgh, Dept Ped. Pittsburgh (336)

2. 9:15 THROID FUNCTION IN INFANTS ADMITTED TO A NEONATAL INTENSIVE CARE UNIT(NICU): A LONGITUDINAL ASSESSMENT. S.Uhrmann, K. H. Marks, M. J. Maisels, Z. Friedman, F. Murray, H. Kulin, M. Kaplan, R. Utiger. Penn. State U. Coll. Med M.S. Hershey Med. Ctr. Dept. Ped, Hershey and U. of Penn Sch. Med, Dept. Med Div. Endo, Philadelphia. (365)

3. 9:30 SERUM LEVELS OF T4, T3 AND TSH DURING THERAPY OF NEONATAL HYPOTHYROIDISM. H. Guyda, J. Letarte, J. Dussault, C. Laberge. Montreal Children's Hosp. Hopital Ste-Justine and C.H.U.L., Quebec. (326)

4. 9:45 MITIGATION OF CRETINISM BY BREAST FEEDING. H. H. Bode, W. J. Vanjonack, J. D. Crawford, Harvard Med. Sch., Shriners Burns Inst., Massachusetts Gen. Hosp. Dept. Of Ped. Boston. (309)

5. 10:00 IMPAIRED SURFACTANT PRODUCTION IN CRETIN LAMBS. M.D. Cunningham, D.R. Holl ingsworth, R.P. Belin (Spon by C.C. Mabry) U. Kentucky, Dept. of Ped. Lexington (316)

\title{
10:15 INTERMISSION
}

6. 10:30 DEXAMETHASONE AND ITS EFFECT ON ADRENAL FUNCTION IN PREMATURES. H. W. Taeucl H. Kamali, A. Hehre, D. Tulchinsky, Dept. of Ped. Ob/Gyn, Harvard Medical Sch. Boston (364)

7. 10:45 HYPERCALCITONEMIA AND NEONATAL HYPOCALCEMIA. H. C. Dirksen, C. S. Anast, H. S. Truman Memorial Veterans Hosp. and Dept. of Child Health, U. of Missouri, Columbia. (318)

8. 11:00 CONTROL OF VASOPRESSIN (AVP) SECRETION IN THE LAMB. R.D.Leake, R.E. Weitzman, J.A. Weinberg, and D.A.Fisher, UCLA Sch. of Med., Harbor General Hosp., Depts. of Ped. and Med., Torrance. (337)

9. 11:15 NEONATAL ISIET CELL ADENOMA. L. C. Deeb, R. A. Ulstrom, U. of Minnesota, Dept. of Ped. Minneapolis. (317)

10. 11:30 STRESS HORMONES IN DIABETIC KETOACIDOSIS. E. Bruck, M. H. MacGillivray, M. L. Voorhess. State U. N.Y. Sch. of Med. Children's Hospital, Dept of Ped. Buffalo. (310) 
ENDOCRINOLOGY

Second Session

April 29, 1977, 9:00 A.M.

Imperial Ball room

Moderators: Claude J. Migeon and Robert P. Kelch

1. 9:00 THE ROLE OF AGGREGATED hGH IN THERAPY OF hGH DEFICIENT CHILDREN. W. V. Moore, (Spon. by C. Cho). U. of Kansas Med. Ctr., Dept of Ped., Kansas City Kansas. (343)

2. 9:15 REPLACEMENT THERAPY WITH HUMAN GROWTH HORMONE (hGH); CONSERVATION VIA LOW DOSAGE AND ROUTINE THYROID (T) REPLACEMENT. A. L. Rosenbloom, M.L. Netzloff, A. D. Garnica, and F. T. Weber (Spon. by 0. M. Rennert). U. of Florida Coll. of Med. Dept. of Ped., Gainesville. (359)

3. 9:30 ACTION OF HUMAN GROWTH HORMONE (hGH) On T3 METABOLISM. I. Rezvani, A. M. DiGeorge, S.A. Dowshen, C. J. Bourdony. Temple U. Sch. of Med., Dept of Ped., St. Christopher's Hosp. for Children, Philadelphia (357)

4. 9:45 EXPERIENCE WITH A NEW RADIOIMMUNOASSAY FOR SOMATOMEDIN-C. R. W. Furlanet to A. J. D'Ercole, L. E. Underwood, J. J. Van Wyk., U. of North Carol ina, Dept. of Ped., Chapel Hill. (325)

5. 10:00 EFFECT OF DEXAMETHASONE (DEX) ON NOCTURNAL SECRETION OF GROWTH HORMONE (GH) PROLACTIN(PRL), GONADATROPINS (GN), ITOH PROGESTERONE (ITOHP) AND GH RESPONSE TO L-DOPA IN PÁTIENTS WITH CONGENITAL ADRENAL HYPERPLASIA (CAH). N. Radfar, K. Trangle, W. Mendelson, F.C. Bartter, (Spon, by A.L. Drash), NIH, Bethesda, (352)

\section{0:15 INTERMISSION}

6. 10:30 SODIUM WASTING WITH NORMAL PLASMA ADOSTERONE (ALDO) CONCENTRATIONS IN SALT LOSING CONGENITAL ADRENAL HYPERPLASIA (SL-CAH). B. S. Keenan, R. T. Kirkland, G. W. Clayton. Dept. of Ped., Baylor Coll. of Med., Houston. (332)

7. 10:45 ALPHA GLYCOPROTEIN HORMONE SUBUNIT ( $\alpha$ ) AFTER LRF IN UNTREATED AND ESTROGEN TREATED GONADAL DYSGENESIS. D. M. Styne, F. A. Conte, S. L. Kaplan, M. M. Grumbach. U. of Calif., Sand Francisco, Dept. of Ped., San Francisco. (363)

8. 11:00 SEXUAL PRECOCITY IN ASSOCIATION WITH SEPTO-OPTIC DYSPLASIA (SOD) AND HYPOTHALAMIC HYPOPITUITARISM. C. A. Huseman, R. P. Kelch, N. J. Hopwood, W. B. Zipf. Dept. of Ped., U. of Mich., Ann Arbor. (327)

9. 11:15 ROLE OF HYPOKALEMIA IN VASCULAR RESISTANCE TO ANGIOTENSIN II (AII). N. Radfar, J. R. Gill,Jr., A. A. Taylor, F. C. Bartter (Spon, by A. L. Drash). NIH, Bethesda. (351)

10. 11:30 EFFECTS OF INDOMETHACIN ON FLUID INTAKE, URINE VOLUME, URINARY PROSTAGLANDINE-LIKE MATERIAL AND KALLIKREIN IN VASOPRESSIN RESISTANT DIABETES INSIPIDUS. H. J. Wohl tmann, P. V. Halushka, P. J. Privitera, H. S. Margolius, R. G. Wagner. (Spon. by J. H. Thurston). Med. U. of South Carolina., Depts. of Ped., Med., and Pharmacology, Charleston. (367) 
April 29,1977 1:30 P.M.

Continental Parlors $7,8, \varepsilon 9$

\section{Moderators: Kenneth D. Rodgers and John Sever}

1. 1:30 IMMUNITY TO DIPHTHERIA IN AN URBAN POPULATION. L.A. Nelson, B.A. Peri C..H. Rieger, R.W. Newcomb, R.M. Rothberg. U. of Chicago Pritzker Sch. of Med. Dept. of Ped., Chicago. (400)

2. 1:45 NATURAL HISTORY OF PROTEUS MIRABILIS (PM) URINARY TRACT INFECTION (UTI) IN INFANCY AND CHILDHOOD. A.J. Khan, R.C. Ubriani, E. Bombach, H. Ratner and H.E. Evans. Jewish Hosp. and Med. Ctr. of Brooklyn, Dept. of Ped., Brooklyn.

3. 2:00 ELECTIVE DELIVERY OF THE "TERM" FETUS - AN OBSTETRICAL HAZARD. M.J. Maisels, R. Rees, K.H. Marks, Z. Friedman. (Spon. by N.M. Nelson), Penn. State U. Coll. Med., M.S. Hershey Med. Ctr. Dept. Ped., Hershey. (394)

4. 2:15 DOWN'S SYNDROME: SHIFTING PATTERNS IN MATERNAL AGE. L.B. Holmes, Genetics Unit, Mass. Gen. Hosp., Boston. (388)

5. 2:30 ESTIMATED RATES OF DOWN'S SYNDROME IN LIVEBIRTHS BY SINGLE YEAR MATERNAL AGE INTERVAL BETWEEN 20-49 and IMPLICATIONS FOR COST-BENEFIT ANALYSIS OF PRENATAL DIAGNOSIS PROGRAMS. E.B. Hook, A. Lindsjo, Birth Defects Institute N.Y.S. Dept. of Health, (and Albany Medical College) Albany, and Eskilstuna, Sweden. (389)

$$
2: 45 \quad \text { INTERMISSION }
$$

6. 3:00 VARIABILITY IN RESPONSE TO LEAD EXPOSURE: DEMONSTRATION OF A GENETIC INFLUENCE. L.D. Penny, J.R. Reigart, C.B. Loadholdt, H.I. Taylor. (Spon. by M.C. Westphal), Med. U. of South Carolina, Depts. of Ped. Biometry, and Lab. Med., Charleston. (401)

7. 3:15 GENETIC FACTORS IN THE DETERMINATION OF HUMAN ADIPOSE TISSUE MASS. F.V. Ginsberg-Fellner, A. Davis, G.J. Bergman, J.S. Schenkein-Stern, J.L. Knittle. Mount Sinai Sch. of Med. N.Y., Dept. of Ped. and Columbia U. Sch. of Dental and Oral Srug., N.Y. (382)

8. 3:30 TRANSMISSIBILITY OF TYPE B HEPATITIS IN A SPECIAL CARE NURSERY. M.A. Gerber, E.B. Lewin, R.J. Gerety, C.T. Le, (Spon. by M.R. Klemperer), U. Rochester, Sch. of Med and Den., Strong Mem. Hosp. Dept. Ped., Rochester. (380)

9. 3:45 HAEMOPHILUS INFLUENZAE TYPE B DISEASE IN A DAY CARE CENTER. C.M. Ginsburg, G.H. McCracken, Jr., J.C. Parke, Jr., Children`s Med. Ctr., Dallas.

10. 4:00 EVOLUTION OF GROUP B STREPTOCOCCAL COLONIZATION IN ASYMPTOMATIC INFANTS. W.T. Speck, R.A. Polin, J.M. Driscoll, H.S. Rosenkranz. Coll. of Physicians and Surgeons, Columbia U. Babies Hosp. Dept. of Ped. N.Y. (403) 


\author{
First Session \\ April 28, 1977, 9:00 A.M. \\ Franciscan Room
}

Moderators: Harry Shwachman and Marvin E. Ament

1. 9:00 TAURINE IN MILK: SPECIES VARIATION. D.K. Rassin, J.A. Sturman,, G.E. Gaull., Div. of Human Development $\varepsilon$ Genetics, Institute for Res. Ment. Retdn., Staten Island, Dept. Ped. Mt. Sinai Sch. Med., Cuny. (463)

2. 9:15 TAURINE IN THE DEVELOPING KITTEN: NUTRITIONAL IMPORTANCE. J.A. Sturman, D.K. Rassin, K.C. Hayes, G.E. Gaull, Div. of Human Develop. and Genetics, Institute for Res. Ment. Retdn., Staten Island, N.Y. Dept. Nutr., Harvard sch. Pub. Hlth., Boston, Dept. Ped. Mt. Sinai Sch. Med., Cuny. (470)

3. 9:30 LITHOGENIC BILE IN CYSTIC FIBROSIS (CF). C.C. Roy, .L. Chartrand, J.C. Combes, A.M. Weber, C.L. Morin, D.Nussle, U. of Montreal and of feneva, Dept. of Ped., Montreal and Geneva. (465)

4. 9:45 ASYMPTOMATIC TRANSIENT UVEITIS IN CHILDREN WITH IMFLAMMATORY BOWEL DISEASE. F. Daum, H.B. Gould, D. Gold, G. Dinari, A.H. Friedman, P. Zucker, M.1. Cohen, Albert Einstein Coll. Med., Montefiore Hosp. \& Med. Ctr., Dept. Ped., Bronx. (426)

5. 10:00 CELLULAR AND ELECTROLYTE CHANGES IN HUMAN BREASTMILK WITH LACTATION. W.B. Pittard, III, D.A. Clark, CWRU Sch. of Med., Dept. of Ped., Cleveland, (Spon. by A. Fanaroff). (459)

\title{
10:15 INTERMISSION
}

6. 10:30 THE INFLUENCE OF HYPERALIMENTATION SOLUTIONS ON INSENSIBLE WATER LOSS (IWL) IN PREMATURE INFANTS. K.H. Marks, T.P. Farrell, Z. Friedman, M.J. Maisels. (Spon. by N.M. Nelson), Penn. State U. Coll. Med. M.S. Hershey Med. Ctr., Dept. Ped., Hershey. (450)

7. 10:45 CHOICE OF TISSUE TO ESTABLISH THE DIAGNOSIS OF MAGNESIUM DEFICIENCY IN AN ANIMAL MODEL FOR THE HUMAN INFANT. J.L. Caddell, R. Scheppner, (Spon. by A.E. McElfresh), Dept. of Ped, and Path., St. Louis U. Sch. of Med., St. Louis. (420)

8. 11:00 CIMETIDINE CAN CONTROL PEPTIC ULCER DISEASE IN CHILDREN. J.R. LillY, D.C. Hitch (Spon. by F.e.'Battaglia), U. of Colorado Sch. of Med., Dept. of Surgery, Denver. (444)

9. 11:15 HEPATIC DYSFUNCTION DURING TOTAL PARENTERAL NUTRITION (TPN). J.C. Collins, A.R. Pulito, W.C. Heird, Columbia Coll. of Phys, and Surg., Dept. of Ped., N.Y. (421)

10. 11:30 SERUM BILE ACIDS IN PROTRACTED DIARRHEA OF INFANCY. J.D. Lloyd-Still, L. Demers (Spon. by H. Nadler), Northwestern U. Med. Sch., Children's Memorial Hosp., Dept. of Ped., Chicago and Dept. of Pathology. The Penn. State U. Coll. of Med., Hershey. (445) 


\title{
GASTROENTEROLOGY AND NUTRITION
}

\author{
Second Session \\ April 29, 1977, 9:00 A.M. \\ Franciscan Room
}

Moderators: Harry Shwachman and Marvin E. Ament

1. 9:00 NONINVASIVE DIAGNOSIS OF SUCROSE INTOLERANCE IN CHILDHOOD BY INTERVAL BREATH HYDROGEN DETERMINATION. J. A. Perman, R. G. Barr, J. B. Watkins, (Spon. by R. J. Grand), Harvard Med. Sch. and Children's Hosp. Med. Ctr., Dept. of Ped., Boston. (458)

2. 9:15 SERUM BILE ACIDS IN PREMATURE INFANTS WITH TPN-ASSOCIATED LIVER DISEASE. A. Garnica, O. M. Rennert, E. Beale. U- of Florida Coll. of Med., Dept. of Ped., Gainesville, (434)

3. 9:30 COMPARATIVE INHIBITORY EFFECTIVENESS OF CHOLESTRYAMINE RESIN AND ACTIVATED ATTAPULGITE ON VIBRIO CHOLERAE ENTEROTOXIN. M. M. Drucker, J. Goldhar, P. I. Ogar, E. Neter., Dept. of Ped., State U. of N.Y. at Buffalo. (429)

4. 9:45 VITAMIN D LEVELS IN THE SERUM OF CYSTIC FIBROSIS PATIENTS. P. M. Farrell, Paul A. di Sant' Agnese. NIH, Bethesda, (431)

5. 10:00 THE EFFECT OF E. COLI ENDOTOXIN ON THE DEVELOPING RAT LIVER: POSSIBLE ROLE IN NEONATAL HEPATITIS. J. M. Andres, W. A. Walker. Harvard Med. Sch. Mass. Gen. Hosp. Ped. GI Units, Boston. (411)

\section{0:15 INTERMISSION}

6. 10:30 EFFECT OF PHOTOTHERAPY FOR NEONATAL JAUNDICE ON RIBOFLAVIN DEPENDENT ENZYMES, GLUCOSE-6-PHOSPHATE DEHYDROGENASE ACTIVITY (G6PD) AND REDUCED GLUTATHIONE (GSH) CONTENT OF BLOOD. L. H. Johnson, T. R. Boggs, M. V. Beirao, U. Pa. Sch. of Med. Pa. Hosp., Dept. Ped., Philadelphia. (439)

7. 10:45 REVERSAL OF GROWTH ARREST IN CROHN'S DISEASE (CD): A NEW APPROACH. R. J. Grand, G. Shen, S. L. Werlin, D. G. KF.LTS, C. Boehm. Children's Med. Ctr., Boston. (433)

8. 11:00 ESPHAGEAL MOTOR DYSFUNCTION IN II PEDIATRIC PATIENTS WITH CHRONIC IDIOPATHIC INTESTINAL PSEUDO-OBSTRUCTION SYNDROME (CIIPS). W. J. Byrne, A. R. Euler, A. F. Ippoliti, M. E. Ament., U. of Calif., Ctr. for Health Sciences, Dept. of Ped. and Med., Los Angeles. (419)

9. $11: 15$ DIAGNOSIS OF EXOCRINE PANCREATIC INSUFFICIENCY IN CYSTIC FIBROSIS (CF) BY A SYNTHETIC PEPTIDE (Bz-Ty-PABA). S. Arvanitakis, C. Arvanitakis, and N. J. Greenberger, (Spon. by C. T. Cho)., U. of Kansas Med. Ctr., Depts of Ped. and Med. Kansas City. (415)

10. 11:30 INTESTINAL ORGAN CULTURE: THE DEFINITIVE DIAGNOSIS OF GLUTEN SENSITIVE ENTEROPHATHY (GSE). A. J. Katz, Z. M. Falchuk (Spon. by R. Grand). Harvard Med. Sch. Children's Hosp. Med. Ctr., Peter Bent Brigham Hosp., Dept. of Ped and.Med., Boston. (441) 
GENETICS

First Session

April 28, 1977, 9:00 A.M.

California Room

Moderators: Kurt Hirschhorn and 0 . W. Jones

1. 9:00 ENZYME MANIPULATION: EVALUATION OF ORAL $\mathrm{ZnSO}_{4}$ SUPPLEMENTATION IN MANNOSIDOSIS TYPE II. G: A. Grabowsik, L. L. Walling, J. U. Ikonne, L. S. Wolfe, R. J. Desnick. U. of Minnesota, Dept. of Ped., Genetics and Cell Biology The Dight Institute for Human Genetics, Minneapolis. (510)

2. 9:15 EARLY TREATMENT OF COMPLETE ORNITHINE TRANSCARBAMYLASE DEFICIENCY WITH KETO ANALOGUES OF ESSENTIAL AMINO ACIDS. J. McReynolds, S. Mantagos, M. Walser, S. Brusilow, J. Rosenberg., Dept. Hunam Genetics, Yale U. Sch. Med. and Depts., Pharm. and Ped., Johns Hopkins Med. Sch., New Haven. (528)

3. 9:30 ENZYME THERAPY: IMMUNE RESPONSE TO ERYTHROCTYE - AND LIPOSOME-ENTRAPPED ENZYME IN B-GLUCURONIDASE DIFICIENT MICE. L. D. Steger, M. B. Fiddler, S. D. Douglas, R. J. Desnick. U. of Minnesota, Dept. of Ped. and Genertics, Minneapolis. (559)

4. 9:45 THE MECHANISM OF HYPERAMMONEMIA IN CITRULLINEMIA. S. Brusilow, M. Batshaw, B. Robinson, G. Sherwood, M. Walser; Johns Hopkins Med. Institute and Hosp. for Sick Children, Baltimore and Toronto. (489)

5. 10:00 CLEFT PALATE: A MOLECULAR MECHANISM LINKED TO THE H-2 LOCUS. A. S. Goldman, M. Katsumata, S. J. Yaffe, D. L. Gasser., Children's Hosp. of Philadelphia, Philadelphis. (508)

\section{0:15 INTERMISSION}

6. 10:30 THE NUMBER OF C-BANDS OF HUMAN ISOCHROMOSOME Xqi AND THIER RELATIONSHIP TO 45, X MOSAICISM. L. Y. F. Hsu, S. Paciuc, K. David, R. Moloshok, K. Hirschhorn. Dept. of Ped., Mt. Sinai Sch. of Med., NYC. (516)

7. 10:45 IDENTIFICATION OF PARTIAL TRISOMY 13 SYNDROME BY DNA REPLICATION STUDIES. B. S. Emanuel, E. H. Zackai, W. J. Mellman. The U. of Penn., Sch. of Med., The Children's Hosp. of Philadelphia, Dept. of Ped., Genetics, Philadelphi. (498)

8. 11:00 To be announced

9. 11:15 HYPERPHENYLALANINEMIA DUE TO PHENYLALANINE HYDROXYLASE COFACTOR DEFICIENCY. S. Milstien, S. Orloff, S. Spielberg, S. Berlow, J. D. Schulman, S. Kaufman, NIMH and NICHD, NIH, Bethesda, and Waisman Center, U. of Wisconsin, Madison (532)

10. 11:30 B-MERCAPTOPYRUVATE SULFUR TRANSFERASE DEFICIENCY. THE ENZYME DEFECT IN B -MERCATOLACTATE CYSTEINE DISULFIDURIA. V. E. Shih, M. M. Carney, L. Fitzgerald V. Monedjikova, Harvard Med. Sch., Mass. Gen Hosp. Dept. of Neurol., Boston and Wrentham State Sch., Wrentham. (555) 


\section{GENETICS}

Second Session

April 29, 1977, 1:30 P.M.

California Room

Moderators: Kurt Hirschhorn and 0 . W. Jones

1. 1:30 NUCLEOSIDE PHOSPHORYLASE DEFICIENCY: IMMUNOLOGIC AND ELECTROPHORETIC EVIDENCE FOR ENZYME HETEROGENEITY. C. R. Scott, W. Osborne, E. Giblett, S. H. Chen, A. Amman, D. Biggar., U. of Washington, U. California; Hosp. for Sick Children, Toronto. (551)

2. $1: 45$ QUANTITATION OF GM $-\beta$-GALACTOSIDASE ( $\beta$-gal) CROSS REACTING MATERIAL (CRM) IN GM, -GANGLIOSIDOSE (GM I-gang). Ben-Yoseph, B. K. Burton, H. L. Nadler Northwestern U. Med. Sch., Children's Memorial Hosp., Dept. of Ped., Chicago (484)

3. 2:00 IMMUNOCHEMICAL ANALYSES IN ORNITHINE TRANSCARBAMYLASE DEFICIENCY. J. W. McReynolds, L. E. Rosenberg, Dept. Human Genet., Yale U. Sch. Med., New Haven (529)

4. 2:15 GAUCHER'S DISEASE: AN ELECTROPHORETIC TECHNIQUE FOR VISUALIZATION OF B -GLUCOSIDASE ISOZYMES FROM LEUKOCYTES AND CULTURED FIBROBLASTS. F. Y. M. ChOY

R. G. Davidson, McMaster U. Med. Ctr. Dept. of Ped, Hamilton, Canada. (493)

5. 2:30 THE DEVELOPMENT OF A LAMBDA PHAGE VECTOR FOR RECOMBINATION CLONING OF MAMMALIAN GENES. R. D. Schmickel, G. N. Wilson, B. M. Hollar, U. of Michigan, Mott Children's Hosp. Dept. of Ped., Ann Arbor. (550)

\section{$2: 45$ INTERMISSION}

6. 3:00 FUNCTIONALLY ABNORMAL $\alpha$ 2-MACROGLOBULIN $\left(\alpha_{2} M\right)$ IN CYSTIC FIBROSIS (CF). E. Shapira, C. Martin, H. Nadler. Northwestern O. Med. Sch., Chlldren's Memorial Hosp. Dept. of Ped., Chicago. (554)

7. 3:15 GENETIC APPROACHES TO ATHEROSCLEROSIS IN PEDIATRIC PATIENTS. HYPERLIPOPROTEINEMIAS I. J. J. Nora, R. B. Winkler, U. of Colorado Sch. of Med. Dept. of Ped., Denver. (537)

8. 3:30 TAY-SACHS DISEASE (TSD): PRENATAL DIAGNOSIS AND HETEROZYGOTE SCREENING, 1969-1976. M. M. Kaback, UCLA-Harbor General Hosp., Dept. of Ped., Torrance . (519)

9. 3:45 ARGININOSUCCINIC ACIDURIA: PRENATAL DIAGNOSIS AND STUDIES OF AN AFFECTED FETUS, L. D. Fleisher, D. K. Rassin, P. Rogers, R. J. Desnick, G. E. Gaull. (Spon. by N. G. Beratis). Div. of Human Devel. E Genet., Institute for Res. Ment. Retdn., Staten Island., Dept. Ped. U. Minnesota, Minneapolis, Dept. Ped., Mt. Sinai Sch. Med., Cuny. (501)

10. 4:00 PRENATAL DIAGNOSIS OF HEMOGLOBIN-H DISEASE BY MOLECULAR HYBRIDIZATION. H. M. Koenig, T. S. Vedvick, M. S. Golbus, A. M. Dosy, Y. W. Kan. (Spon. by W. L. Nyhan), Naval Med. Ctr., U. of Callfornia, San Diego, U. of California San Francisco. (523) 


\author{
HEMATOLOGY AND ONCOLOGY \\ First Session \\ April 28, 1977, 9:00 A.M. \\ Continental Parlors 7,8 , \& 9
}

Moderators: Aaron R. Rausen and fieorge R. Honig

1. 9:00 CHOICE OF BLOOD FOR EXCHANGE TRANSFUSION (ET) IN THE NEONATE: IN VITRO STUDY OF COAGULATION FACTORS AND MICROAFGREGATES. D.R. Barnard, R.G. Chapman, M.A. Simmons, W.E. Hathaway, U. of Colorado, Med. Ctr., Depts. of Ped. Med., Denver. (571)

2. 9:15 METABOLIC CHARACTERISTICS OF CORD BLOOD ERYTHROCYTES STUDIED AT REDUCED OXYGEN TENSION. F.A. Oski, R. Cittadino, Suny, Upstate Med. Ctr., Syracuse. (640)

3. 9:30 A FETAL ISOZYME OF PHOSPHOFRUCTOKINASE IN NEWBORN ERVTHROCYTES. Shobhana, Vora, S. Piomelli, New York U. Med. Sch., Dept. of Ped. (668)

4. 9:45 DIAMOND-BLACKFAN SYNDROME: IN VITRO ANALYSIS OF THE ERYTHROPOIETIC DEFECT. M.H. Freedman, F. Saunders, U. of Toronto, Hosp. for Sick Children, Dept. of Ped., Toronto. (598)

5. 10:00 IRON DEFICIENCY ANEMIA IN CHILDREN WITH JUVENILE RHEUMOTOID ARTHRITIS (JRA). M.A. Koerper, D.A. Stemple, J.J. Miller, III, P.R. Dallman. U. of California Med. Ctr., Dept. of Ped., San Francisco and Children's Hosp. at Stanford, Dept. of Ped., Stanford. (612)

\title{
10:15 INTERMISSION
}

6. 10:30 CONTINUOUS IV AND SC DESFERRIOXAMINE THERAPY IN BETA-THALASSEMIA. A.L. Markenson, J.H. Graziano, H. Chang, M. Bestak, P. Meyers, P. Pisciotto, D.R. Miller, New York Hosp., Cornell Med. Ctr., Dept. of Ped., New York. (625)

7. 10:45 SCINTIGRAPHIC DETECTION OF BONE AND BONE MARROW INFARCTS IN SICKLE CELL DISORDERS. H.C. Kim, A. Alavi, M.O. Russell, E. Schwartz, Depts. of Ped. and Nuclear Med., U. of Pa. Sch. of Med. (610)

8. 11:00 IMMUNOCHEMICAL DIAGNOSIS OF HEMOGLOBINOPATHIES IN THE FETUS AND NEWBORN INFANT. V.E. Headings, S.I.0. Anyaibe, S.P. Bhat tacharya, E.L. Hopkins. Howard U. Coll. of Med., Dept. of Ped. and Child Health, The Center for Sickle Cell Disease, and Dept. of Obstetrics and Gynecology, Washington, D.C. (605)

9. 11:15 QUANTITATION OF HUMAN PROTHROMBIN BY RADIOIMMUNOASSAY (RIA). C.D. LOX, T. Mikel, G.H. Strohm, J.J. Corrigan, Jr., U. of Arizona Health Science Center, Tucson. (621)

10. 11:30 THE ROLE OF THE HUMORAL IMMUNE SYSTEM IN CHILDHOOD IDIOPATHIC THROMBOCYTOPENIC PUPURA (ITP). A.L. Lightsey, R. McMillan, H.M. Koenig, I. Schulman, Naval Regional Med. Ctr. and Scripps Clinic, San Diego, and Stanford U., Stanford. (620) 
HEMATOLOGY AND ONCOLOGY

Second Session

April 29, 1977, 9:00, A.M.

Continental Parlors $7,8 \& 9$

Moderators: Aaron R. Rausen and George R. Honig

1. 9:00 CELL ELASTIMETRY IN THE DETECTION OF IMMUNE NEUTROPENIA -- DEMONSTRATION OF A Membrane PERTURBation. M, E. Miller, L. A. Boxer. UCLA and Indiana U. Schs. of Med., Harbor General Hosp. and J. W. Riley Hosp. for Children,Depts. of Ped. Torrance, and Indianapolis. (633)

2. 9:15 AUTONOMOUS PRODUCTION OF PARATHORMONE BY LYMPHOBLASTIC LEUKEMIA CELLS IN CULTURE. N. K. C. Ramsay, W. Krivit, M. E. Nesbit, R. Yip, D. M. Brown. U. of Minnesota Sch. of Med. and Hospitals, Dept. of Ped. Minneapolis. (642)

3. 9:30 CHILDHOOD LYMPHOBLASTIC MALIGNANCY: SUBGROUPS DEFINED BY NONHUMAN PRIMATE ANTISERA. R. B. Raney, T. Mohanakumar, R.S. Metzgar, H. Hann, M. H. Donaldson. Children's Hosp., Philadelphia, Duke U. Med. Ctr. Durham, and Fox Chase Cancer Ctr., Philadelphia. (644)

4. 9:45 CIRCULATING COLONY-FORMING CELLS IN CHILDHOOD LEUKEMIA. Jen-Yih Chu, P. Freiling, D. O'Connor, A. McElfresh. St. Louis, U. Sch. of Med. Cardinal Glennon Memorial Hosp. for Children, Dept. of Ped., St. Louis. (587)

5. 10:00 CENTRAL NERVOUS SYSTEM (CNS) PROPHYLAXIS IN ACUTE LYMPHATIC LEUKEMIA (ALL)-SPINAL FLUID THROMBOPLASTIC ACTIVITY (TA) AS AN INDICATOR OF CNS INJURY J. E. Graeber, M. J. Stuart. Dept. of Ped., Suny, Upstate Med. Ctr., Syracuse. (601)

\section{0:15 INTERMISSION}

6. 10:30 TERMINAL TRANSFERASE AND VINCRISTINE-PREDNISONE RESPONSIVENESS IN Ph' CHROMOSOME (+) LUEKEMIAS. M. Fosburg, T. Padre-Mendoza, P. Smith, T. A. Harrison, H. J. Kim, Y. Burstein, A. R. Rausen, E. Forman, R. McCaffrey. (Spon. by B. Glader) Harvard Med. Sch. Sidney Farber Cancer Institute., Children's Hosp., Boston; Mt. Sinai Sch. of Med. Beth Israel Hosp., New York; Brown U., Rhode Island Hosp. Providence (597)

7. 10:45 ABNORMALLY LOW P50 IN PATIENTS WITH MALIGNANCIES. R. S. Festa, T. Asakura Dept. of Ped. Children's Hosp., Philadelphia. (596)

8. 11:00 IMPAIRED PRODUCTION OF T LYMPHOCYTE MITOGENIC LYMPHOKINES AND MONOKINES IN PEDIATRIC MALIGNANT DISEASE. S. Leikin, E. Esber, J. Oppenheim, George Washington U. Sch. of Med. Children's Hosp., Washington, D.C. and NIDR, National Institute of Health, Bethesda. (618)

9. 11:15 INTERFERON - DEMONSTRATION OF IN VITRO ANTITUMOR ACTIVITY AGAINST OSTEOGENIC SARCOMA CELLS. L. A. Glasgow, J. L. Crane,Jr., E. R. Kern. U. of Utah, Coll. of Med., Dept. of Ped., Salt Lake City. (600)

10. 11:30 RADIATION-INDUCED GANGLIONEUROBLASTOMA AND NEURAL TUMORS. B. Jayalakshmamma, R. Chilcote, W. Recant, M. Colman, (Spon. by E. Moore). Pritzker Sch. of Med. U. of Chicago, Michael Reese Hosp. and Med Ctr., Dept. of Ped. and Path. and Radiation Oncology, Chicago. (607) 
IMMUNOLOGY

First Session

April 28, 1977, 9:00 A.M.

Pacific Room

Moderators: E. Richard Steihm and Erwin W. Gelfand

1. 9:00 ALLERGEN-INDUCED DEPRESSION OF NEUTROPHIL CHEMOTAXIS IN ATOPIC INDIVIDUALS. J. L. Rubin H. R. HIII., U. of Utah, Dept. of Ped, and Pathology Salt Lake City. (729)

2. 9:15 VENOM IMMUNOTHERAPY FOR HONEYBEE STING-SENSITIVE PERSONS. J. W. Yunginger, B. R. Paull, G. J. Gleich (Spon. by G. S. Gilchrist), Depts. of Ped., Int. Med., and Immunol., Mayo Clinic and Foundation, Rochester. (751)

3. 9:30 RICE ALLERGY AND CNS REACTIONS AND SERUM COMPLEMENT DEPRESSION. R. C. Strunk J. L. Pinnas, T. J. John, R. C. Hansen, J. L. Blasovich. Dept. of Ped and Med., U. of Arizona Health Sciences Ctr, Tucson. (742)

4. 9:45 NORMAL AND ABERRANT B-CELL DIFFERENTIATION IN BONE MARROW. E. R. Pearl, L. B. Vogler, W. M. Crist, A. R. Lawton, M. D. Cooper of Alabama in Birmingham, Children's Hosp. Dept. of Ped. and Microbiology, Birmingham. (719)

5. 10:00 SUPPRESSION OF PLASMA CELL DIFFERENTIATION BY PRIMED T LYMPHOCYTES. A. R. Hayward (Spon. by A. R. Lawton) Dept. of Ped., U. of Alabama in Birmingham. (695)

10:15 INTERMISSION

6. $10 \$ 30$ LOCALIZATION OF C-REACTIVE PROTEIN IN SYNOVIUM OF PATIENTS WITH RHEUMATOID ARTHRITIS. J. D. Gitlin, J. I. Gitlin, D. Gitlin. U. Pittsburgh, Dept. of Ped., Pittsburgh (690)

7. 10:45 TETANUS SKIN TEST: DOES IT ASSESSDELAYED HYPERSENSITIVITY? T. C. BorUt B. J. Ank, E. R. Stiehm, UCLA Sch. of Med. Dept. of Ped., Los Angeles. (679)

8. 11:00 THE USE OF DIPHTHERIA AND TETANUS TOXOIDS TO ASSESS CELL-MEDIATED IMMUNITY (CMI). S. P. Galant, N. Flod, I. Shimizu,G. A. Granger. (Spon.by T. L. Nelson). U. California, Irvine, California Coll. of Med. U. of California Irvine, Affiliated Hosp., Dept. of Ped., Irvine. (689)

9. $11: 15$ CELL MEDIATED IMMUNE RESPONSE TO LIVER SPECIFIC ANTIGENS FOLLOWING HEPATITIS B VIRUS INFECTION IN MAN. M. L. Tiku, K. R. Beutner, K. Tiku, P. L. Ogra. SUNY at Buffalo. (744)

10. 11:30 THE BREASTMILK MACROPHAGE: A POTENTIAL VEHICLE FOR IMMUNOGLOBULIN TRANSPORT W. B. Pittard, 111 ., S. Polmar, A. Fanaroff, CWRU. Ped. Dept., Cleveland. (721) 
IMMUNOLOGY

Second Session

April 29, 1977, 1:30 P.M. Hilton Plaza

Moderators: E. Richari Stiehm and Erwin W. Gelfand

1. 1:30 IMMUNOGLOBULIN PRODUCTION IN SEVERE COMBINED IMMUNODEFICIENCY DISEASE (SCID) AFTER THYMUS EPITHELIAL EXPLANT THERAPY. J.F. Jones, O.E. Sieber, J. Pinnas, R. Hong, V.A. Fulginiti. U. of Arizona, Tucson, and U. of Wisconsin, Madison. (700)

2. 1:45 IN VITRO AND IN VIVO DEFINITION OF A NEW VARIANT OF SEVERE COMBINED IMMUNODEFICIENCY DISEASE (SCID). A. Shore, H. Dosch, J. Huber, E.W. Gelfand. The Hosp. for Sick Children, Dept. of Immunology and Path., Toronto. (735)

3. 2:00 LYMPHOCYTIC INTRACYTOPLASMIC INCLUSIONS IN INFANTS WITH A VARIANT OF SEVERE COMBINED IMMUNODEFICIENCY $(S C I D)$. O.F. Sieber,Jr., J.F. Jones, C.M. Payne, V.A. Fulginiti, Dept. of Ped. and Path., U. of Arizona, Tucson. (737)

4. 2:15 HUMAN LYMPHOCYTE TRANSFORMATION FOLLOWING INHIBITION OF PURINE NUCLEOSIDE PHOSPHORYLASE. U. Ochs, W. Osborne, S.H. Chen, C.R. Scott, U. of Washington, Dept. of Ped. Seattle. (716)

5. 2:30 DEFECTIVE ACTIVATION OF THE TERMINAL COMPLEMENT ( ${ }^{\prime}$ ) COMPONENTS IN NEWBORN SERA. J. Winkelstein, L. Kurlandsky, A. Swift. Johns Hopkins U. Sch. of Med., Dept. of Ped., Baltimore. (750)

\section{$2: 45 \quad$ INTERMISSION}

6. 3:00 MONOCYTES FROM PATIENTS WITH GENETIC DEFICIENCY OF THE THIRD COMPONENT OF COMPLEMENT (C3) PRODUCE C3 IN VITRO. L.P. Einstein, P.J. Hansen, C.A. Alper, J.S. Davis, F.S. Rosen, M. Ballow, H.R.Colten, Harvard U., U. of Va., and U. of Conn., Med. Sch. and Children's Hosp. Med. Ctr., Boston. (686)

7. 3:15 MONOCYTE CHEMOTAXIS IN HEALTH AND DISEASE. T.J. Fischer, R.B. Klein, T.C. Borut, S.E. Gard, G.S. Rachelefsky, E.R. Stiehm. UCLA Sch. of Med. Dept of Ped., Los Angeles. (688)

8. 3:30 CONGENITAL LEUKOCYTE MOVEMENT DISORDER AND RECURRENT INFECTIONS. T.A. Howard, J.A. Winkelstein, M.F. Tsan, W.H. Zinkham, Johns Hopkins Hosp., Dept. of Ped. and Med., Baltimore. (697)

9. 3:45 LYMPHOCYTE MOTILITY IN CHRONIC LYMPHOCYTIC LEUKEMIA (CLL) AND X-LINKED HYPO- $\gamma$-GLOBULINEMIA. A.S. Goldman, F.C. Schmalstieg, H.B. Rudloff, R.M. Goldblum, J.B. Alperin. Dept. of Ped.and Med., U. of Texas Med. Branch Galveston. (692)

10. 4:00 MEASLES REVACCINATION: THE PERSISTENCE AND DEGREE OF ANTIBODY RESPONSE ANALYZED BY TYPE OF IMMUNE RESPONSE. J. Deseda-Tous, J.D. Cherry, M.J. Spencer, R.C. Welliver, K.M. Boyer, J.P. Dudley, J.M. Zahradnik, P.J. Krause, Dept. Ped., UCLA, Los Angeles. (685) 


\section{INFECTIOUS DISEASE}

First Session

April 28, 1977, 9:00 A.M. Hilton Plaza

Moderators: David H. Carver and James C. Overall, Jr.

1. 9:00 ADENINE ARABINOSIDE THERAPY OF HERPES SIMPLEX ENCEPHALITIS: NIAID COLLABORATIVE ANTIVIRAL STUDY GROUP. R. J. Whitley, R. Dol in, G. J. Galasso, L. T. Ch'ien, C. A. Alford and the Collaborative Study Group. Dept. of Ped. U. of Alabama in Birmingham. and the NIH, Bethesda. (825)

2. 9:15 ADENINE ARABINOSIDE THERAPY OF VARICELLA ZOSTER IN IMMUNOCOMPROMISED PATIENTS. R. J. Whitley, R. Dolin, G. J. Galasso, C. A. Alford and the Collaborative Study Group. Dept., of Ped., U. of Alabama in Birmingham, and the NIH, Bethesda. (826)

3. 9:30 SUCCESSFUL CHEMOPROPHYLAXIS FOR PNEUMOCYSTIS CARINII PNEUMONITIS (PCP) W. Hughes, S. Kuhn, S. Chaudhary, S, Feldman, M. Verzosa, R. Aur, C. Pratt Infectious Diseases and Hematology-Oncology Services, St. Jude Children's Research Hosp., Memphis (776)

4. 9:45 PHARYNGEAL IMPLANTATION OF ALPHAHEMOLYTIC STREPTOCOCCI (ESTREP) IN NEONATES IN AN ICU. K. Sprunt, G. Leidy and W. Redman, Columbla U. Coll. of Phys, and Surg., Dept. of Ped., Div. of Infect. Dis. New York City. (807)

5. 10:00 HAEMOPHILUS INFLUENZAE, THE PREDOMINANT CAUSE OF BACTERIAL PNEUMONIA IN HAWAII. A. R. Potter, G. W. Fischer. (Spon. by J. W. Bass). Dept. of Ped. Tripler Army Medical Center, Honolulu. (795)

\section{0:15 INTERMISSION}

6. 10:30 RAPID DIAGNOSIS OF H. INFLUENZAE TYPE B (HIB) INFECTIONS BY LATEX PARTICLE AGGLUT INATION (LPA) AND COUNTER IMMUNOELECTROPHORESIS (CIE). J. I. Ward, G. R. Siber, D. W. Scheifele, D. H. Smith. Children's Hosp. Med. Ctr., Dept. of Med. Boston. (824)

7. 10:45 DETECTION OF BACTERIAL ANTIGENS BY STAPHYLOCOCCAL COAGGLUTINATION TEST M. C. Thirumoorthi, A. S. Dajani, Dept. of Ped, Wayne State U., Detroit. (819)

8. 11:00 VENTRICULAR INVOLVEMENT IN HAEMOPHILUS INFLUENZAE TYPE B (HIB) MENINGITIS. R. S. Daum, D. W. Scheifele, V. Syriopoulou, A. L. Smith. Children's Hosp. Med. Ctr., Dept. of Med., Boston (761)

9. 11:15 SYNERGY OF AMPICILLIN AND CHLORAMPHENICOL AGAINST HAEMOPHILUS INFLUENZAE. W. E. Feldman, (Spon. by J. D. Nelson), U. of Texas Southwestern Med. Sch. Dept. of Ped., Dallas (766)

10. 11:30 VIREMIA IN HYPERPYREXIC CHILDREN. T. Yamauchi, D. T. Imagawa, M. Y. Nishita, J. A. Gammon, E. G. Vollman. Harbor Gen. Hosp. UCLA Sch. of Med, and Arkansas Children's Hosp. Dept. of Ped. Torrance, Callfornia and Little Rock. (829) 


\title{
INFECTIOUS DISEASE
}

\author{
Second Session \\ April 29, 1977, 9:00 A.M. \\ Hilton Plaza
}

Moderators: David H. Carver and James C. Overall, Jr.

1. 9:00 PREVENTION OF ENDOTOXIN EFFECTS IN GRAM-NEGATIVE SEPTICEMIA MODEL WITH POLYMYXIN B. J.J. Corrigan, Jr., J.F. Kiernat. Dept. of Ped., U. of Arizona Health Sciences Ctr., Tucson. (758)

2. 9:15 EFFECT OF METHYL-PREDNISOLONE AND POLYMIXIN B-SULPHATE ON ENDOTOXIN INDUCED INHIBITION OF HUMAN NEUTROPHIL CHEMOTAXIS. A.C. Issekutz, M. Ng. and W.D. Biggar (Spon. by A. Sass-Kortsak). Dept. of Ped., Immunol., The Hosp. for Sick Children, Toronto. (780)

3. 9:30 COUNTERCURRENT IMMUNOELECTROPHORESIS (CIE) OF RESPIRATORY SECRETIONS IN THE DIAGNOSIS OF PNEUMONIA. B.L. Congeni, G.A. Nankervis (Spon. by D.N. Medearis). Case Western Reserve U. Sch. of Med. at Cleveland Metropolitan General Hosp. Dept. of Ped., Cleveland. (757)

4. 9:45 ROLE OF ANTIBODY AND THE CLASSICAL AND ALTERNATIVE COMPLEMENT PATHWAYS ON THE OPSONIZATION OF GROUP B STREPTOCOCCI. A.O. Shigeoka, R.T. Hall, V.G. Hemming, H.R. Hill, Dept. of Ped. and Path., U. of Utah, Salt Lake City and Children's Mercy Hosp., Kansas City. (802)

5. 10:00 TEICHOIC ACID SEROLOGY IN VARIOUS STAPHYLOCOCCAL COAGULASE POSITIVE INFECTIONS IN INFANTS AND CHILDREN. C.T. Le, E.B. Lewin, (Spon, by M.R. Klemperer). U. of Rochester Sch. of Med. and Dent., Strong Memorial Hosp. Dept. of Ped., Rochester. (783)

\section{0:15 INTERMISSION}

6. 10:30 INFECTIONS IN NEONATAL DEATHS. L. Eisenfeld, R. Ermocilla, J. Sowder, R. Galloway, D. Wirtschafter, B. Riley, M. McDevitt, G. Cassady, Div. of Perinatal Med. and Dept. of Path., U. of Alabama, Birmingham. (764)

7. 10:45 PERSISTENCE OF MIDDLE EAR EFFUSION AFTER OTITIS MEDIA. S.I. Pelton, P.A. Shurin, J.0. Klein. Harvard Med. Sch., Boston, U. Sch. of Med., Boston City Hosp., Dept. of Ped., Boston. (793)

8. 11:00 SUSCEPTIBILITY OF E. COLI INFECTION IN NEONATES WITH GALACTOSEMIA. H.L. Levy, S.J. Sepe, M.R. Hammerschlag, M. Lansky, J.O. Klein. State Lab Inst., Mass., Dept. Pub. Health, Harvard Med. Sch., Mass. Gen. Hosp., and Boston City Hosp., Boston. (785)

9. 11:15 DIFFERENCE IN BEHAVIOR OF INFLUENZA A AND B VIRUSES IN INFANT RATS: VIRAL MULTIPLICATION IN NASAL TURBINATES AND POTENTIATION OF BACTEREMIC INFECTION WITH H. INFLUENZAE TYPE B. R.H. Michaels, R.L. Myerowitz, F.L. Ruben, U. of Pittsburgh Sch. of Med., Pittsburgh. (789)

10. 11:30 VARICELLA-ZOSTER VIREMIA: ASSOCIATION WITH PROGRESSIVE VARICELLA. M.G. Myers (Spon. by R.G. Strauss), U. of lowa Hosp., Dept. of Ped., lowa City. (791) 


\author{
METABOLISM \\ First Session \\ April 29, 1977, 9:00 A.M. \\ Pacific Room
}

Moderators: Donough O'Brien and M. Michael Thaler

1. 9:00 INSULIN DELAYS THE MORPHOLOGIC MATURATION OF FETAL RAT LUNG IN VITRO. 1. Gross, G. J. W. Smith. (Spon. by J. B. Warshaw) Yale U. Sch. of Med. Depts. of Ped. and Path., New Haven. (861)

2. 9:15 INSULIN-CARBOHYDRATE RELATIONSHIP IN THE SHEEP FETUS. A. F. Philipps, B. S. Carson, G. Meschia, F. C. Battaglia., U. of Colorado Med. Ctr. Div. of Perinatal Med., Denver. (891)

3. 9:30 UPTAKE OF GLUCOSE AND RELEASE OF GLUCONEOGENIC PRECURSORS BY THE HINDLIMB OF THE FASTING BABOON NEONATE. L. L. Levitsky, J. B. Paton, D. E. Fisher, C. W. De Lannoy. Pritzker Sch. Med., U. Chicago, Michael Reese Hosp. Med. Ctr., Dept. Peds., Chicago. (876)

4. 9:45 EFFECT OF DIETARY PROTEIN AND MAGNESIUM ON PLASMA CHOLESTEROL IN WEANLING RATS. J. L. Caddell (Spon. by A. E. McElfresh). Dept. of Ped.and Path. St. Louis U. Sch. of Med., St. Louis. (841)

5. 10:00 NEONATAL EFFECTS OF $1,25(\mathrm{OH})_{2}$ Vitamin $D_{3}$ ON IONIZED Ca (iCa), Ca ABSORPTION AND PARATHYROID HORMONE (PTH). G. M. Chan, R. C. Tsang, I. W. Chen, H. DeLuca, J. J. Steichen, U. of Cincinnati \& U. of Wisconsin. (844)

\title{
10:15 INTERMISSION
}

6. 10:30 HYPERAMMONEMIA IN PREMATURE INFANTS: M. Batshaw, S. Brusilow, Johns Hopkins Med. Institute., John F. Kennedy Institute., Dept. of Ped., Baltimore (835)

7. 10:45 UREA CYCLE ENZYMES AND OROTIC ACID (OD) IN REYE'S SYNDROME (RS). M M. Thaler, B. Beiderman. U. of Calfornia, Dept. of Ped, San Francisco. (906)

8. 11:00 DIHYDROLIPOYL DEHYDROGENASE DEFICIENCY - A CAUSE OF CONGENITAL LACTIC ACIDOSIS. B. H. Robinson, J. Taylor, W. G. Sherwood (Spon. by D. Fraser), The Hosp. for Sick Children Research Inst., Toronto. (894)

9. 11:15 CROTONASE DEFICIENCY: DEMONSTRATION OF A DEFECT IN $\beta$-OXIDATION IN MAN J. C. Williams, M. W. Haymond, R. E. Hillman. Washington Sch. Med., Dept. of Ped., St. Louis Children's Hosp. St. Louis. (911)

10. 11:30 THE ENZYMIC BASIS FOR THE PHENOTYPIC VARIATION OF HURLER AND SCHEIE SYNDROMES. R. Matalon, M. Deanching, (Spon. by 1. M. Rosenthal). Abraham Lincoln Sch. of Med. Dept. Ped., U. of 111. Chicago. (887) 


\section{METABOLSIM}

Second Session

April 29, 1977, 1:30 P.M.

Pacific Room

Moderators: Donough O'Brien and M. Michael Thaler

I. 1:30 HYPOPHOSPHATEMIC BONE DISEASE (HBD) OF CHILDHOOD: A "NEW"' ENTITY. W. MacDonald, C. R. Scriver, T. Reade, B. Nogrady, F. H. Glorieux, H. F. Deluca Dept. of Ped, McGill U. and Shriners Hosp. Montreal, Que., Dept. of Biochemistry, U. Wisconsin, Madison. (882)

2. 1:45 USE OF 2-DEOXYGLUCOSE AS AN ALTERNATIVE TO FASTING FOR DIAGNOSIS OF HYPOGLYCEMIA. I. L. Hansen, M. M. Levy, D. S. Kerr, (Spon. by M. H. Klaus), Case Western Reserve Med. Sch. U. Hosp. of Cleveland, Dept. Of Ped., Cleveland (862)

3. 2:00 GLUCAGON RESPONSES IN LEUCINE-SENSITIVE HYPOGLYCEMIA. T. F. Roe, (Spon. by M. D. Kogut), USC Sch. of Med. Childrens Hosp. of Los Angeles, Dept. of Ped., Losangeles. (895)

4. 2:15 FRUCTOSE 1:6 DIPHOSPHATASE DEFICIENTCY: ? A DIAGNOSTIC PITFALL. A. J. Macnab. (Spon. by S. Israels) U. of British Columbia, Dept. of Ped. Vancouver. (883)

5. 2:30 HYPERURICEMIA IN GLYCOGEN STORAGE DISEASE TYPE I (GSD-1). H. L. Greene F. Wislon, P. Hefren, A. Terry, A. Slonim, 1. Burr, Dept. of Ped, and Dept. of Med., Vanderbilt U. Hosp., Nashville. (860)

\section{$2: 45$ INTERMISSION}

6. 3:00 DEVELOPMENT OF MICROVASCULAR DISEASE IN CHILDREN WITH DIABETES. J. 1. Malone, T. C. Van Cader, M.P. Steinberg, (Spon. by L. A. Barness), U. of South Florida Coll. of Med. Depts. of Ped and Ophthalmology, Tampa. (885)

7. 3:15 URINARY ACIDIC GLYCOHYDROLASE AS AN INDEX OF EARLY RENAL DAMAGE IN JUVENILE DIABETES MELLITUS (JDM). E. Kohler, K. J. Sheth, T. A. Good, Med. Coll. of Wisconsin, Milwaukee Children's Hosp. Dept. of Ped., Milwaukee (873)

8. 3:30 NORMOTRIGLYCERIDEMIC ABETALIPOPROTEINEMIA - CLINCICAL AND BIOCHEMICAL FEATURES OF A NEW SYNDROME. M. J. Malloy, J. P. Kane. (Spon. by A. J. Ammann) U. of California, Sch. of Med., Dept. of Ped. and Cardiovascular Research Inst. San Francisco. (884)

9. 3:45 FAMILIAL HYPERTRIGLYCERIDEMIA IN CHILDREN: DIETARY THERAPY. C. J. Glueck, M. J. Mellies, R. C. Tsang, P.M. Steiner. U. of Cincinnati, Coll. of Med. General Clinical Research Ctr-, Cincinnati. (854)

10. 4:00 PREDNISOLONE PHARMACOKINETICS IN CHILDREN: O. C. Green, F. S. Kawahara, R. J. Winter, P. R. Lewy, L. M. Pachman, Northwestern U. Med. Sch., Dept. of Ped. The Children's Memorial Hosp., Chicago. (859) 
April 29, 1977, 1:30 P.M.

Cabrillo/Dolores Rooms

Moderators: David W. Smith and Owen M. Rennert

1. 1:30 ORIGIN OF CALVARIAL SUTURES IN RELATION TO DURAL REFLECTIONS: NORMAL DEVELOPMENT AND PREDICTABLE ALTERATIONS SECONDARY TO BRAIN MALFORMATION. D.W. Smith, G. Tondury, U. of Washington Sch. of Med. Dysmorphology Unit, Dept. of Ped., Seattle, Anatomisches Institute, U. of Zurich. (948)

2. 1:45 THE MURINE Ah LOCUS AND DYSMORPHOGENESIS. S. Shum, G.H. Lambert, D.W. Nebert, (Spon. by J. Schulman). NICHD, NIH, Bethesda. (947)

3. 2:00 SMALL MOLECULAR WEIGHT HYDROXYPROLINE-CONTAINING COMPOUNDS IN THE DEVELOPING MOUSE LIMB. L.B. Holmes, R.L. Trelstad, Mass. Gen. Hosp. and Shriner's Burns Institute, Boston. (927)

4. 2:15 THE EFFECTS OF MODERATE ALCOHOL CONSUMPTION DURING PREGNANCY ON FETAL GROWTH AND MORPHOGENESIS. J.W. Hanson, A.P. Streissguth, D.W. Smith, U. of Washington, Sch. of Med. Ped., Seattle. (926)

5. 2:30 CLINICAL AND BIOCHEMICAL EFFECTS OF VITAMIN D (D) ON PREGNANT RABBITS AND THEIR OFFSPRING. D. Mehlhorn, G.M. Chan, J.J. Buchino, K.E. Bove, J.J. Steichen, L. Abrams, R.C. Tsang, U. of Cincinnati. (936)

\section{$2: 45$ INTERMISSION}

6. 3:00 EFFECT OF LUNG BUD EXCISION ON CARDIOPULMONARY DEVELOPMENT IN THE CHICK. E.B. Clark, D.R. Martini, G.C. Rosequist., Dept. of Ped., U. Nebr. (917)

7. 3:15 MATERNAL SERUM ALPHA-FETOPROTEIN (AFP) SCREENING FOR NEURAL TUBE DEFECTS (NTDS). A. Milunsky, E. Alpert, F.D. Frigoletto. Harvard Med. Sch. Eunice Kennedy Shriver Ctr., Mass. Gen. Hosp., Boston Hosp. for Women, Depts. Ped., Med. and Obstet. Gynecol., Boston. (937)

8. 3:30 TRICHO-RHINO-PHALANGEAL (TRP) SYNDROME: VARYING EXPRESSIVITY AND PROGRESSION OF SKELETAL ABNORMALITIES. J.L. Frias, A.H. Felman, A.D. Garnica, S.E. Wallace (Spon. by $0 . M$. Rennert), U. of Florida Coll. of Med., Dept. of Ped. and Radiology, Gainesville. (922)

9. 3:45 THE COFFIN-SIRIS (CS) SYNDROME. J.C. Carey, B.D. Hall, (Spon. by C.J. Epstein) Dept. of Ped., U. of Calif., San Francisco. (916)

10. 4:00 FURTHER HETEROGENEITY I.H LETHAL NEONATAL SHORT-LIMBED DWARFISM. W.A. Horton, D.L. Rimoin, D.W. Hollister, R.S. Lachman, UCLA-Harbor Gen. Hosp., Div. of Med., Gen., Torrance. (928) 


\author{
NEONATOLOGY \\ First Session \\ April 29, 1977, 9:00 A.M. \\ Continental Ball room \#4
}

Moderators: Nicholas M. Nelson and Harry Bard

1. 9:00 ASSESSMENT OF GESTATIONAL AGE BY EXAMINATION OF THE ANTERIOR

VASCULAR CAPSULE OF THE LENS. N.J. Hirsch, H.M. Hittner, A.J. Rudolph, Baylor Coll, of Med., Jefferson Davis Hosp., Dept. of Ped., and Ophthal., Houston. (979)

2. 9:15 HIGH-FREQUENCY MECHANICAL VENTILATION OF LOW-BIRTH-WEIGHT INFANTS WITH RESPIRATORY FAILURE FROM HYALINE MEMBRANE DISEASE: 92\% SURVIVAL. R.D. BI and, M.H. Kim, M.J. Light, J.L. Woodson, (Spon. by W.H. Tooley). Dept. of Ped., U. of Hawai i and U. of Calif., Cardiovascular Res. Inst., San Francisco. (958)

3. 9:30 EFFECT OF $\mathrm{HCO}_{3}$ - THERAPY ON ACID-BASE HOMEOSTASIS IN NEWBORN DOCS WITH AND WITHOUT VENTILATORY RESTRICTION. J.J. Steichen, L.l. Kleinman, U. of Cincinnati Coll. of Med., Dept. of Ped., Cincinnati. (1028)

4. 9:45 LARYNGEAL CHEMOREFLEX - NEWBORN APNEA AND SUDDEN INFANT DEATH SYNDROME (SIDS). 1. Kovar, U. Selstam, W.Z. Catterton, M.B. Escobedo, H. Sundell, M.T. Stahlman., Dept. of Ped., Vanderbilt U., Nashville. (986)

5. 10:00 UPPER AIRWAY OBSTRUCTION DURING APNEIC SPELLS IN PRETERM INFANTS. B.T. Thach, A.R. Stark, (Spon. by C.H. Smith). Washington U. and Harvard Med. Sch., St. Louis Children's Hosp., Boston Hosp. for Women, Depts. Ped., St. Louis, Boston. (1029)

\title{
10:15 INTERMISSION
}

6. 10:30 CONTINUOUS MONITORING OF $\mathrm{PO}_{2}$ IN NEONATES WITH APNEA. M. Hiatt, L. Indyk, T. Hegyi, B. Dangman, F. Caceres, A. Moessinger, R. Wynn., L.S. James, Coll. of Phys. and Surg., Col. U. Dept. of Ped., N.Y. (978)

7. 10:45 THE RELATIONSHIP BETWEEN APNEA AND HEART RATE IN PREMATURE INFANTS. J.C. Rowe, W.J. Flanagan, W.A. Hodson, D.E. Woodrum. U. of Washington Sch. of Med., Dept. of Ped., Seattle. (1019)

8. 11:00 "DISORGANIZED BREATHING"- AN IMPORTANT FORM OF APNEA AND CAUSE OF HYPOXIA. J.L. Peabody, A.G.S. Philip, J.F. Lucey, U. of Vt. Coll. of Med., Dept. of Ped., Burlington. (1009)

9. 11:15 EVIDENCE THAT ENDORPHIN (S) MODIFY THE RESPIRATORY RESPONSE IN NEONATAL ASPHYXIA. V. Chernick, D.L. Madansky, E.E. Lawson, Dept. of Ped., Harvard Med. Sch., Boston. (962)

10. 11:30 EFFECT OF CAFFEINE ON CONTROL OF BREATHING. J.V. Aranda, M. Mazzarelli, L. Tamas, M.J. Sergysels, J. Milicemilli. (Spon. by E. Colle), Roche Dev. Pharm. Unit and Depts. of Physiol. Ped. Pharm., McGill U. Dept. of Newborn Med. Montreal Children's Hosp., Montreal. (954) 


\section{NEONATOLOGY \\ Second Session \\ April 29, 1977, 1:30 P.M. Continental Ball room \#4}

Moderators: Nicholas M. Nelson and Harry Bard

1. 1:30 INTERMITTENT PHOTOTHERAPY: EFFECT ON INTRACELLULAR DNA. W.T. SPECK R.M. Santella, H.S. Rosenkranz, Coll. of Phys. and Surg. Columbia U., Babies Hosp., Dept. of Ped., N.Y. (1026)

2. 1:45 MECHANISMS FOR FETAL EXCRETION OF HEPATOTOXIC MONOHYDROXY BILE ACIDS. E.R. Brown, J.B. Watkins. (Spon. by H.W. Taeusch) Harvard Med. Sch. and Children's Hosp. Med. Ctr., Dept. of Ped., Boston. ( 960$)$

3. 2:00 INFLUENCE OF HEME ON THE KINETICS OF BILIRUBIN BINDINF. A.H. DaWOdU, J.M. Sutherland, L.E. Becker, W.J. Keenan, U. of Cinti., Coll. of Med., Dept. of Ped., Cincinnati. (964)

4. 2:15 LIGHT ENHANCED BILIRUBIN TOXICITY IN CULTURED LYMPHOCYTES. S. Shankaran, R.L. Poland, S.N. Cohen, Dept. of Ped., Wayne State Sch. of Med. And Children's Hosp. of Michigan, Detroit. (1022)

5. 2:30 BINDING OF BILIRUBIN IN NEONATAL SERUM STUDIED BY FLUORESCENCE QUENCHING R.L. Levine (Spon. by F.C. Battaglia). U. of Colorado, Med. Ctr., Div. of Perinatal Med., Denver. (989)

\section{2:45 INTERMISSION}

6. 3:00 NITRO-BLUE TERTAZOLIUM (NBT) TEST IN BACTEREMIC NEONATES. B.D. Chandler. N. Kapoor, B. Barker, R. Boyle, W. Oh, Brown U., Program in Med., Women and Infants Hosp. of R.1., Dept. of Ped., Providence. (961)

7. 3:15 NEW STANDARDS FOR "BASAL" HEAT PRODUCTION AND EVAPORATIVE AND NONEVAPORATIVE HEAT LOSS IN LOW BIRTH WEIGHT NEWBORN INFANTS? A. Okken, J.H.P. Jonxis, P. Rispens, W.G. Zylstra, (Spon. by M. Klaus), Dept. of Ped., State U. Groningen, Netherlands. (1003)

8. 3:30 THE EFFECT OF CLOTHING ON THE GROWTH OF VERY LOW BIRTHWEIGHT (VLBW) INFANTS, K.H. Marks, S.B. Uhrmann, Z. Friedman, M.J. Maisels. (Spon. by N.M. Nelson), Penn. State U. Coll. Med., M.S. Hershey Med. Ctr. Dept. Ped., Hershey. (996)

9. 3:45 THE COST OFLIVING FOR INFANTS $\leq 1000$ GMS AT BIRTH. J. Pomerance, C. Ukrainski, T. Ukra, (Spon. by B.M. Kagan). Cedars-Sinai Med. Ctr. $(C S M C)$. Dept. of Ped, and UCLA Sch. of Med., Los Angeles.

(59)

10. 4:00 EARLY RETRANSFER: A METHOD OF OPTIMAL UTILIZATION OF NICU BEDS. M. Zarif, J. Rest, D. Vidyasagar, Dept. of Ped., ALSM, U. of $111 .$, Chicago. 


\author{
NEPHROLOGY \\ First Session \\ April 29, 1977, 9:00 A.M. \\ Continental Parlors $1,2 \& 3$
}

Moderators: Adrian Spitzer and Pedro A. Jose

1. 9:00 GLOMERULAR CAPILLARY VOLUME AND SURFACE AREA DURING ONTOGENY.

E.John, D. 1. Goldsmith, C. M. Edelmann,Jr., A. Spitzer., Albert Einstein Coll. of Med. Dept. of Ped., Bronx. (1084)

2. 9:15 EFFECT OF POLYCYTHEMIA ON RENAL FUNCTION IN NEWBORN DOGS. U. R. Kotagal, T. Disney, L. I. Kleinman, U. of Cincinnati Coll. of Med., Dept. of Ped., Cincinnati. (1092)

3. 9:30 RENAL PhOSPHATE CLEARANCE IN FETAL LAMBS. B. S. Moore, E. E. Chung, E. E. Cevallos, B. J. McMann, M. Ocampo, E. Lyons. Dept. of Ped., Pritzker Sch. Med. U. of Chicago at Michael Reese Med. Ctr., Chicago. (1098)

4. 9:45 SUGAR TRANSPORT IN ISOLATED NEWBORN RAT RENAL TUBULES: A POSSIBLE EXPLANATION FOR ABSENCE OF NEONATAL GLUCOSURIA. K. S. Roth, Shing-Mei Hwang, Marc Yudkoff, Stanton Segal, Children's Hosp. of Philadelphia, U. Penn. Sch. of Med., Philadelphia. (1108)

5. 10:00 SODIUM BALANCE IN VERY LOW BIRTH WEIGHT INFANTS. S. C. Engleke, B. L. Shah U. Vasan, J. R. Raye, U. of Conn. Health Ctr., Dept. of Ped., Farmington. (1067)

\title{
10:15 INTERMISSION
}

6. 10:30 LATE METABOLIC ACIDOSIS (LMA): A REASSESSMENT. G.J. Schwartz G.R. Haycock, C. M. Edelmann, Jr., A. Spitzer, Albert Einstein Coll. of Med. Dept. of Ped., Bronx. (1114)

7. 10:45 CO-EXISTENCE OF DISTAL RENAL TUBULAR ACIDOSIS (dRTA) AND NEPHROGENIC DIABETES INSIPIDUS (NDI) IN TWO PATIENTS: IMPLICATIONS FOR THE PATHOGENESIS OF DISTAL RENAL TUBULAR ACIDOSIS. J. Balfe, A. Folami, B. Stinebaugh, $M$. Halperin., Dept of Ped. Med. U. of Toronto and Baylor Coll. of Med. Houston (1052)

8. 11:00 ANTIBODY RESPONSE TO A GLOMERULONEPHRITIS RELATED STREPTOCOCCAL ANTIGEN. I. Sagel, K. Lange, G. Treser, E. Wasserman. Renal Service, Dept. of Med., N.Y. Coll. New York. (1110)

9. 11:15 THE SIGNIFICANCE OF ELECTRON DENSE DEPOSITS IN MILD LUPUS NEPHRITIS. D. T. Domoto, N. J. Siegel, M. Kashgarian., Depts. of Ped and Path., Yale Sch. of Med., New Haven. (1065)

10. 11:30 CHRONIC UNILATERAL HYDRONEPHROSIS-EVALUATION OF RENAL FUNCTION. J. Friedman J. R. Hoyer, B. Rucker, J. E. Lewy, Cornell U. Med. Coll. Dept. of Ped., N.Y. (1072) 


\author{
NEPHROLOGY \\ Second Session \\ April 29, 1977, 1:30 P.M. \\ Continental Parlors $1,2 \& 3$
}

Moderators: Adrian Spltzer and Pedro A. Jose

1. 1:30 DEVELOPMENT OF GLOMERULAR PERMEABILITY IN THE NEWBORN LAMB. M. 0. Lim, C. W. Trygstad, UCLA-Harbor Gen Hosp., Dept. of Ped. Torrance. (1093)

2. 1:45 EFFECT OF GLOMERULAR POLYANION REMOVAL ON PROTEINURIA. E. R. ROOT S. B. Conley, A. M. Robson, Wash. U. Sch. of Med. Dept. of Ped., St. Louis. (1104)

3. 2:00 FAMILIAL NEPHRITIS, A VARIANT OF ALPORT'SSYNDROME?. N. B. Vicente, D. B. Bhathena, N. H. Holland. Dept. of Ped and Path. U. of Kentucky, Med. Ctr., Lexington. (1125)

4. 2:15 A USEFUL BIOCHEMICAL MARKER IN THE IDENTIFICATION OF HEREDITARY NEPHRITIS: HYDROXYLYSINE GLYCOSIDES (OHLG'S). L. U. TINa, M. LOU. D. DiZio, Dept. of Ped. Georgetown U. Sch. of Med., Washington, D.C. and Alfred I. DuPont Inst., Dept. of Biochem., Wilmington. (1123)

5. 2:30 RADIORECEPTOR ASSAY FOR SOMATOMEDIN-A IN UREMIC CHILDREN. W. C. ArnOId, E. M. Spencer, K. Uthne, C. F. Piel, M. A. Holliday. U. of California, Depts., of Ped and Med., San Francisco. (1048)

\title{
$2: 45$ INTERMISSION
}

6. 3:00 HYPERLIPIDEMIA IN CHRONIC RENAL INSUFFICIENCY (CRI): THE ROLE OF PARATHORMONE (PTH). Z Papadopoulou, L. Tina, P. Sandler, P. Jose, P. Calcagno. Dept of Ped., Georgetown U. Sch. of Med. Washington, D.C. (1102)

7. 3:15 CELL METABOLISM IN UREMIA. J. Metcoff, R. Lindeman, D. Baxter., U. of Oklahoma Health Sciences Center \& Veteran's Ad. Hosp., Depts. of Ped. and Med., Oklahoma City. (1097)

8. 3:30 ANTIBODIES TO B-LYMPHOCYTES IN RENAL TRANSPLANTATION. R. B. Ettenger, P. I. Terasaki, M. H. Malekzadeh, C. H. Uitterbogaart, A. J. Pennisi, R. Fine. U. of So. Cal. Sch. Med. Childrens Hosp., Los Angeles and U. Calif Sch,Med. (1069)

9 - 3:45 SODIUM EXCRETION ( $U$ V) AND RENAL CORTICAL RENIN CONTENT (RCRC) IN ACUTE EXPERIMENTAL RENAL FÁlLURE (ARF). A. K. Bidani, L. E. Fleischmann, P. Churchill (Spon by S. Cohen) Wayne State, Children's Hosp. of Michigan, Detroit. (1055)

10. 4:00 AMELIORATION OF ACUTE RENAL FAILURE WITH ATP-MgCl 2 INFUSION. $N$. J. Siegel, M. B. Osias, I. H. Chaudy. Depts., of Ped and Sur., Yale Sch of Med., New Haven. (1117) 


\section{NEUROLOGY}

April 29, 1977, 1:30 P.M. Anza/Balboa Rooms

Moderators: John M. Freeman and Darryl C. DeVivo

1. 1:30 PARASAGITTAL CEREBRAL INJURY IN NEONATAL HYPOXIC-ISCHEMIC ENCEPHOLOPATHY: CLINICAL AND NEURORADIOLOGIC FEATURES. J.J. Volpe, J.F. Pasternak, Washington U. Sch. of Med., St. Louis Children's Hosp., Depts. Of Ped. and Neurol.. St. Louis. (1167)

2. 1:45 CEREBRAL INTRAVENTRICULAR HEMORRHAGE (CVH) IN INFANTS $\leq 1500$ FRAMS. L. Papile, J. Burstein, R. Burstein, (Spon. by R. Greenberg). U. of New Mexico Sch. of Med., Dept. of Ped. Albuquerque. (1155)

3. 2:00 CLINICAL SIGNIFICANCE OF INTRACRANIAL PRESSURE (ICP) MONITORING IN ACUTELY ILL NEONATES. D. Vidyasagar,T.N.K. Raju, J. Chlang, Dept. of Ped. ALSM, U. of $111 .$, Chicago. (1166)

4. 2:15 LESS THAN 1000 GM INFANT, IMMEDIATE AND LONGTERM OUTCOME. R. Bhat, T.N.K. Raju, D. Vidyasagar. ALSM, U. of 111., Chicago. (1134)

5. 2:30 NEUROBEHAVIORAL ASSESSMENT OF WELL \& ILL PREMATURES OF $\leq 32$ WEEKS GESTATION. D.T. Scott, J.R. Farwell, (Spon. by J.B. Warshaw). Yale U. Sch. of Med. Depts. of Ped. \& Psychol., New Haven. (1161)

\section{$2: 45$ INTERMISSION}

6. 3:00 NERVOUS SYSTEM LESIONS IN INFANTS OF OPIATE DEPENDENT MOTHERS. I.B. Rorke, D.S. Reeser, L.P. Finnegan, (Spon. by M. Delivoria-Papadopoulos). U. of Penn. Sch. of Med., Thomas Jefferson U., Phila. Gen. Hosp. (PGH). (1160)

7. 3:15 ALTERATIONS IN THE FUNCTIONAL ORGANIZATION OF THE STRIATE CORTEX OF THE NEWBORN MONKEY IN RESPONSE TO MONOCULAR VISUAL DEPRIVATION. C. Kennedy, M. Des Rosiers, 0. Sakurada, L. Sokoloff. Georgetown U. Sch. of Med., Dept. of Ped., Washington, D.C. and National Institutes of Mental Health, Lab. of Cerebral Metabol., Bethesda. (1149)

8. 3:30 STROKE SYNDROME IN SICKLE CELL DISEASE (SCD). D.R. Powars, C.H. Pegelow, B.J. Wilson, J.P. Allen, (Spon. by F. Wehrle). U. of Southern California Sch. of Med., Los Angeles County U. of Southern California Med. Ctr., Dept. of Ped., Los Angeles. (1157)

9. 3:45 ELEVATED CONCENTRATIONS OF CSF HOMOVANILLIC ACID IN REYE SYNDROME: A POSSIBLE RELATION TO CEREBRAL HYPOPERFUSION. B.A. Shaywitz, J.L. Venes, D.J. Cohen, M.B. Bowers, Jr., Dept. of Ped., Neurosurg., and Psych., Yale U. Sch. of Med., New Haven. (1162)

10. 4:00 CHRONIC KETOSIS AND CEREBRAL METABOLISM. D.C. DeVivo, M.P. Leckie, J.A. Ferrendelli, Wash. U. Depts. of Ped. and Neurol., St. Louis. (1136) 
First Session

April 28, 1977, 9:00 A.M. Continental Ballroom \#4

Moderators: William W. Waring and Samuel T. Giammona

1. 9:00 ALTERATION IN NEONATAL RESPIRATORY FUNCTION FOLLOWING CHEST PHYSIOTHERAPY W. W. Fox, J. G. Schwartz, T. H. Shaffer, (Spon by J.A. Cortner). U. of Pa. Sch. of Med., Depts., of Ped. and Physlol. and The Children's Hosp. of Phila. Philadelphia. (1192)

2. 9:15 THE EFFECT OF DIFFERENT HEAD POSITIONS ON THE WORK OF BREATHING IN VERY LOW BIRTH WEIGHT INFANTS WITH ENDOTRACHEAL TUBES. A. R. Wilkinson J. C. McQuitty, M. M. Willis, William H. Tooley. Cardlovascular Research Inst. and Dept. of Ped. U. of Calif., San Francisco. (1258)

3. 9:30 PULMONARY IRRITANT REFLEXES IN NEWBORN INFANTS. P. Fleming, H. Bryan A, C. Bryan. Research Institute. The Hospital for Sick Children, Toronto.

4. 9:45 SYSTEMIC BLOOD PRESSURE RESPONSE TO CONTINUOUS POSITIVE AIRWAY PRESSURE (CPAP) IN INFANTS WITH HYALINE MEMBRANE DISEASE (HMD). F. Waffarn,

L. A. Cabal, J. E. Hodgman. Dept. of Ped., U. of So. Calif., Sch. of Med. Los Angeles County-USC, Med. Ctr. (1255)

5. 10:00 EFFECTS OF CPAP VIA ENDOTRACHEAL TUBE ON ORGAN BLOOD FLOWS IN NEWBORN LAMBS. C. R. Rosenfeld, D. E. Fixler, G. Gabriele, M. Wheeler, J. West U. Tex. Health Sci., Ctr., Dept. of Ped. Dallas. (1238)

\section{0:15 INTERMISSION}

6. 10:30 CONTINUOUS MONITORING OF ARTERIAL PCO $2\left(\mathrm{P}_{2} \mathrm{CO}_{2}\right)$ BY NON-INVASIVE TRANSCUTANEOUS METHOD. A. V. Beran, J. J. Munoz, G. Y. Shigezawa, R. F. Huxtable, (Spon, by T. L. Nelson). U. of Calif. Coll. of Med., Dept. of Ped., Irvine. (1175)

7. 10:45 NEBULIZATION OF SONICATED PHOSPHOLIPIDS (PL) FOR TREATMENT OF RESPIRATORY DISTRESS SYNDROME (RDS) OF INFANCY. H. I vey, S. Roth, J. Kattwinkel (Spon. by R. Blizzard)., U. of Va., Dept. of Ped. and Johns Hopkins U., Dept. of Biol. (1207)

8. 11:00 ESSENTIAL FATTY ACIDS (EFA), PROSTAGLANDINS (PGS) AND HYALINE MEMBRANE DISEASE (HMD). Z Friedman, Lawrence Demers, (Spon, by N. M. Nelson).,Penn. State U. Coll. Med. M.S. Hershey Med. Ctr. Dept. Ped. and Path. Hershey. (1196)

9. 11:15 EFFECT OF VITAMIN E DEFICIENCY ON PULMONARY OXYGEN TOXICITY. R. L. POIaND R. O. Bollinger, M.E. Bozynski, P. Karna, E. V. D. Perrín. Depts. of Ped and Path., Wayne State Sch. of Med. and the Children's Hosp. of Michigan, Detroit. (123!

10. $11: 30$ EVIDENCE FOR AMELIORATION OF BRONCHOPULMONARY DYSPLASIA (BPD) FOLLOWING VITAMIN E ADMINISTRATION. R. A. Ehrenkranz, B. W. Bonta, R. C. Ablow, J. B. Warshaw, Yale U. Sch. of Med., Depts of Ped., and Diagnostic Radiology, New Haven. (1187) 


\section{PULMONOLOGY}

Second Session

Apri1 29, 1977, 1:30 P.M. Continental Ball room \#5

Moderators: William W. Waring and Samuel T. Giammona

1. 1:30 SYNERGISTIC EFFECTS OF POLYCYTHEMIA (P) AND HYPOXIA (H) ON PULMONARY VASCULAR RESISTANCE IN DOGS. R.L. McGrath, J.V. Weil (Spon. by F.C. Battaglia). Dept. of Ped. and Cardiovas. Pulmonary Research Lab. „U. of Colorado, Sch. of Med., Denver. (1223)

2. 1:45 PULMONARY FUNCTION STUDIES FOLLOWING BILATERAL LUNG LAVAGE IN PREMATURE LAMBS. T.H. Shaffer, J.D. Ferguson, M. Delivoria-Papadopoulos. U. of Penn., Sch. of Med., Dept. of Physiol., Philadelphia. (1241)

3. 2:00 VENTILATION AND PERFUSION ASSESSMENT BY ELECTRICAL IMPEDANCE PLETHYSMOGRAPHY. J.A. Spence, T.R. Weng, G. Polgar, J. Nyboer. Dept. of Ped. and Physiol., Wayne State U. and Childrens Hosp. of Mich., Detroit. (1248)

4. 2:15 MORPHOLOGICAL ANALYSIS OF THE PULMONARY VASCULAR BED (PVB) IN CONGENITAL LEFT-SIDED DIAPHRAGMATIC HERNIA (CLDH). D.L. Levin (Spon. by D. Fixler). U. of Texas Health Sci. Ctr., Dept. of Ped., Dallas. (1214)

5. 2:30 VENTILATORY MUSCLE TRAINING IN CYSTIC FIBROSIS. T.G. KeenS, I.R.B. Krastins, E.M. Wannamaker, A.C. Bryan, H. Levison, D.N. Crozier. Research Institute Hosp. of Sick Children, Toronto. (1209)

\section{$2: 45$ INTERMISSION}

6. 3:00 PULMONARY WASHINGS AND BLOOD IN PULMONARY ALVEOLAR PROTEINOSIS (PAP). L. Sieger, J.A. Stratton, K. Wasserman, (Spon. by B.F. Anthony). UCLA Sch. Med., Harbor Gen. Hosp., Depts. Ped. E Med. Torrance. (1245)

7. 3:15 NEGATIVE PLEURAL PRESSURES AND PULMONARY EDEMA IN ACUTE CHILDHOOD ASTHMA. S.A. Stalcup, R.B. Mellins, Coll. of Phys, and Surg., Columbia U. Dept. of Ped., N.Y. (1249)

8. 3:30 DESQUAMATIVE INTERSTITIAL PNEUMONIA IN INFANCY AND CHILDHOOD. I.R. Harwood, N. Olmsted, S.T. Giammona. U. of Calif. Med. Ctr. Dept. of Ped. San Diego. (1206)

9. 3:45 PATTERNS OF HYPOXEMIA IN INFANTS WITH RESPIRATORY SYNCTIAL VIRUS (RSV) BRONCHIOLITIS AND PNEUMONIA, MEASURED BY EAR OXIMETRY. C.B. Hall, W.J. Hall, D.M. Speers (Spon. by D.H. Smith). U. of Rochester Sch. of Med., Dept. of Ped. and Med., Rochester. (1203)

10. 4:00 OXYGEN TOXICITY: COMPARISON OF LUNG BIOCHEMICAL RESPONSES OF NEONATAL AND ADULT RATS. L. Frank, J. Yam, R.J. Roberts, U. of lowa, Dept. of Ped. and Pharm., lowa City. (1194) 